

\section{Wind Turbine Micropitting Workshop: A Recap}

\section{Technical Report NREL/TP-500-46572 \\ February 2010}

\section{Shuangwen Sheng, Editor}

Prepared under Task No. WE101131

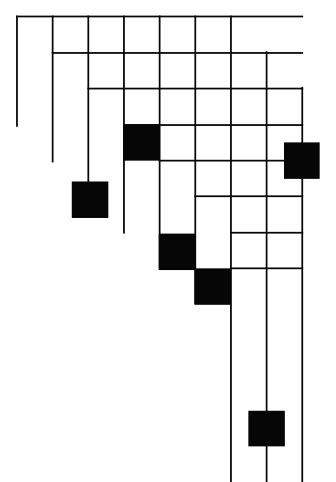

National Renewable Energy Laboratory

1617 Cole Boulevard, Golden, Colorado 80401-3393

303-275-3000 • www.nrel.gov

NREL is a national laboratory of the U.S. Department of Energy

Office of Energy Efficiency and Renewable Energy

Operated by the Alliance for Sustainable Energy, LLC

Contract No. DE-AC36-08-GO28308 


\section{NOTICE}

This report was prepared as an account of work sponsored by an agency of the United States government. Neither the United States government nor any agency thereof, nor any of their employees, makes any warranty, express or implied, or assumes any legal liability or responsibility for the accuracy, completeness, or usefulness of any information, apparatus, product, or process disclosed, or represents that its use would not infringe privately owned rights. Reference herein to any specific commercial product, process, or service by trade name, trademark, manufacturer, or otherwise does not necessarily constitute or imply its endorsement, recommendation, or favoring by the United States government or any agency thereof. The views and opinions of authors expressed herein do not necessarily state or reflect those of the United States government or any agency thereof.

Available electronically at http://www.osti.gov/bridge

Available for a processing fee to U.S. Department of Energy and its contractors, in paper, from:

U.S. Department of Energy

Office of Scientific and Technical Information

P.O. Box 62

Oak Ridge, TN 37831-0062

phone: 865.576 .8401

fax: 865.576 .5728

email: mailto:reports@adonis.osti.gov

Available for sale to the public, in paper, from:

U.S. Department of Commerce

National Technical Information Service

5285 Port Royal Road

Springfield, VA 22161

phone: 800.553.6847

fax: 703.605.6900

email: orders@ntis.fedworld.gov

online ordering: http://www.ntis.gov/ordering.htm 


\section{Foreword}

Micropitting is a Hertzian fatigue phenomenon that affects many wind turbine gearboxes, and it affects the reliability of the machines. With the major growth and increasing dependency on renewable energy, mechanical reliability is an extremely important issue. The U.S. Department of Energy has made a commitment to improving wind turbine reliability and the National Renewable Energy Laboratory (NREL) has started a gearbox reliability project. Micropitting as an issue that needed attention came to light through this effort. To understand the background of work that had already been accomplished, and to consolidate some level of collective understanding of the issue by acknowledged experts, NREL hosted a wind turbine micropitting workshop, which was held at the National Wind Technology Center in Boulder, Colorado, on April 15 and 16, 2009. Attendees agreed that it would be a small meeting of experts that allowed open discussion. To that end, it was also agreed that no formal proceedings would be published. The consensus of attendees, however, was that the workshop content was so valuable that a summary of the content and conclusions should be prepared. This report was developed for that purpose. The presentations given at the workshop can be downloaded at:

http://wind.nrel.gov/public/Wind_Turbine_Gearbox_Micropitting_Workshop_2009.zip

Interested readers who were not at the workshop may wish to consult the detailed publications listed in the bibliography, obtain the cited articles in the public domain, or contact the authors directly. 


\section{Acknowledgments}

This workshop was organized by a small committee, but its tremendous value was realized because of the contributions of many. The concept of the workshop came from Bob Errichello (GEARTECH). His longstanding experience in wind turbine gearbox failure analysis and his contact with many world-class experts enabled him to suggest both the format and most of the speakers. We are deeply indebted to him not only for his contributions for this workshop but also for his continuous contributions to wind turbine gearbox reliability.

Shawn Sheng (NREL) provided all the organizational and logistical planning. He has the good technical insight into the technical topics needed to accomplish this task. He did an excellent job and clearly was the main reason for the success of the workshop.

Peter Blau (Oak Ridge National Laboratory [ORNL]) collaborated on determining the technical content, writing this report, and guiding the organization of the workshop. His contributions were a key to making the meeting a success. He brought a perspective of material science to the discussion and meeting organization.

Sandy Butterfield (NREL) gave the wind turbine context and related it to broad gearbox reliability issues.

The speakers were by far the main attraction. Each one was a recognized expert who brought a new and different perspective of micropitting and how it could affect wind turbine reliability. The organizers want to express their deepest thanks to them for their efforts. 


\section{Contents}

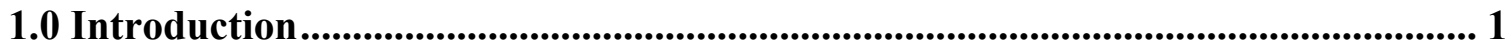

2.0 Summary of Presentations ........................................................................................ 4

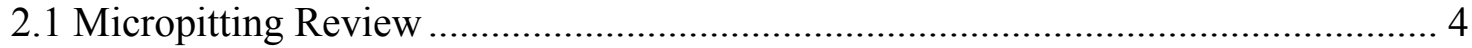

2.1.1 State of the Art: Micropitting......................................................................... 4

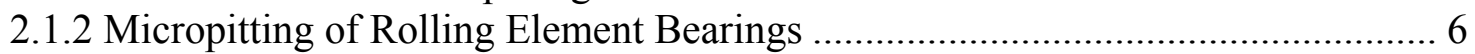

2.2 Lubricant Effects on Micropitting ......................................................................... 8

2.2.1 Fundamentals of Tribochemistry, Wear, and Surface Property Control ............... 8

2.2.2 Influence of Lubricant Chemistry on Micropitting ............................................. 10

2.2.3 Rolling Contact Fatigue (RCF): Lubricant Effects ........................................ 10

2.3 Characterization and Testing ....................................................................... 12

2.3.1 Helical versus Spur Gears ................................................................................ 12

2.3.2 Survey of Micropitting Research Work of Germany's FVA and Status of Work

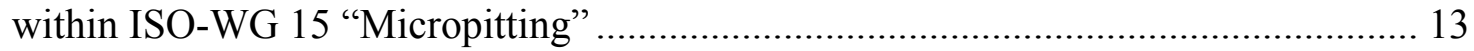

2.3.3 Systematic Tribology Test Methods for Micropitting .......................................... 14

2.3.4 Gear Testing to Aid the Understanding of Micropitting...................................... 16

2.3.5 Analytical and Experimental Methods for Micropitting Research ....................... 18

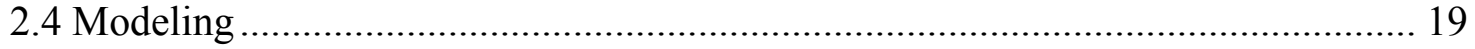

2.4.1 Micropitting, Micro-EHL, and Mixed Lubrication............................................ 19

2.4.2 Modeling Micropitting: The CAT Model ....................................................... 20

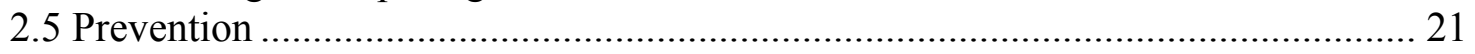

2.5.1 How to Prevent Micropitting ………………............................................... 21

3.0 Summary and Conclusions..................................................................................... 23

3.1 Possible Causes for Prevalence of Micropitting in Wind Turbines ......................... 23

3.2 Test Rigs and Strategy for Wind Turbine Micropitting.......................................... 23

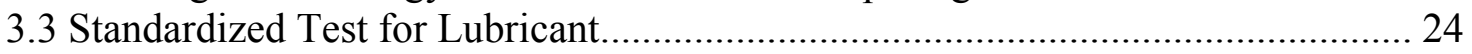

3.4 Run-in Procedure for Wind Turbine Gearboxes .................................................. 24

3.5 Needs for Further Research and Testing............................................................... 24

4.0 Bibliography ................................................................................................................. 30

Appendix A: Information on Attendees.............................................................................. 38

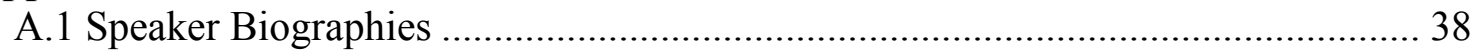

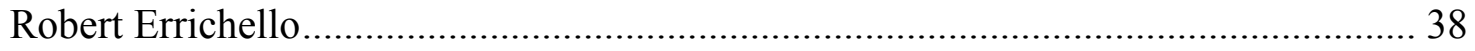

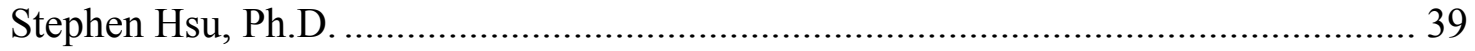

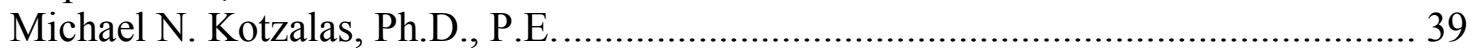

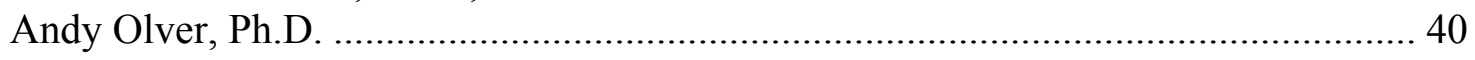

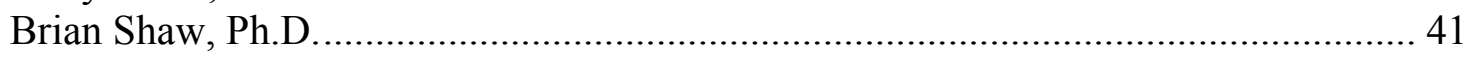

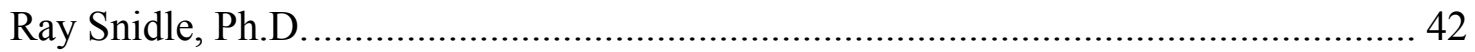

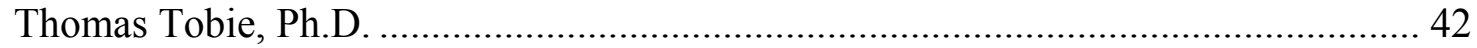

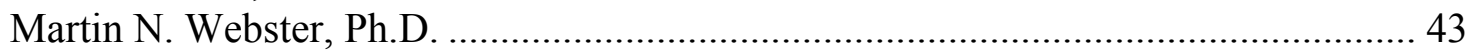

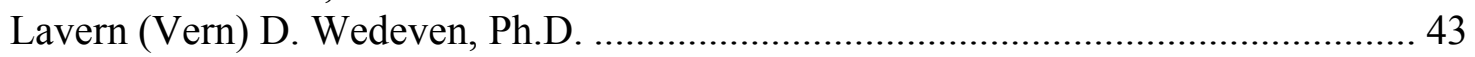

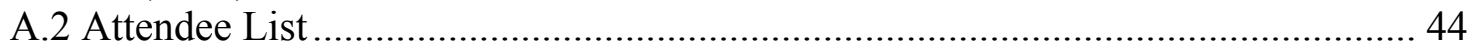

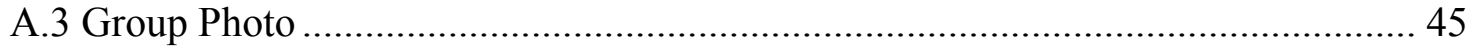




\subsection{Introduction}

Micropitting is a form of localized surface damage that is prevalent in wind turbine gearboxes, and it occurs on both gear teeth and bearings. It is especially detrimental to bearing function because it alters the geometry of rollers, raceways, or both. The altered geometry increases internal clearance and results in edge stresses that ultimately cause macropitting and bearing failure. It is not known why micropitting occurs frequently in wind turbine gearboxes, but the unique operation and environment may each contribute. Perhaps widely varying loads, rapid accelerations, and high vibration levels promote micropitting. Contamination by water is common in wind turbine gearboxes and could also be a contributing factor.

The National Renewable Energy Laboratory's (NREL) micropitting workshop was conceived to (1) establish what is known about micropitting from prior research and (2) define what additional research may be necessary to prevent micropitting in wind turbine gearboxes.

Thirteen presentations by leading tribologists covered many aspects of micropitting in gears and bearings, including data from the field and laboratory and both analytical and experimental analyses. Thirty-two delegates representing 21 organizations from three different countries attended the workshop and participated in the discussions. Table 1-1 gives the workshop agenda, and a summary of the concluding discussion follows the table. Section 2 summarizes each presentation, and Section 3 presents conclusions. Appendix A contains the speakers' biographies, along with a list of attendees and a group photo. 
Table 1-1. Workshop Agenda

\begin{tabular}{|c|c|c|}
\hline \multicolumn{3}{|c|}{ Day 1: April 15, 2009} \\
\hline Time & Topic & $\begin{array}{l}\text { Speaker and } \\
\text { Affiliation }\end{array}$ \\
\hline 9:00 a.m. & Introduction & $\begin{array}{l}\text { Sandy Butterfield, } \\
\text { NREL }\end{array}$ \\
\hline \multicolumn{3}{|c|}{ Session 1: Overview of Micropitting, Mechanistic Causes, and Modeling } \\
\hline 9:30 a.m. & State of the Art: Micropitting & $\begin{array}{l}\text { Robert Errichello, } \\
\text { GEARTECH }\end{array}$ \\
\hline 10:20 a.m. & $\begin{array}{l}\text { Fundamentals of Tribochemistry, Wear, and Surface } \\
\text { Property Control }\end{array}$ & $\begin{array}{l}\text { Stephen Hsu, George } \\
\text { Washington } \\
\text { University }\end{array}$ \\
\hline 11:00 a.m. & Micropitting of Rolling Element Bearings & $\begin{array}{l}\text { Michael Kotzalas, } \\
\text { The Timken } \\
\text { Company }\end{array}$ \\
\hline 1:30 p.m. & $\begin{array}{l}\text { Survey of Micropitting Research Work of Germany's FVA } \\
\text { and Status of Work within ISO-WG } 15 \text { "Micropitting" }\end{array}$ & $\begin{array}{l}\text { Thomas Tobie, FZG- } \\
\text { TU-Munich }\end{array}$ \\
\hline 2:20 p.m. & Micropitting, Micro-EHL, and Mixed Lubrication & $\begin{array}{l}\text { Ray Snidle, Cardiff } \\
\text { University }\end{array}$ \\
\hline 3:20 p.m. & Modeling Micropitting: The CAT Model & $\begin{array}{l}\text { Andy Olver, Imperial } \\
\text { College }\end{array}$ \\
\hline \multicolumn{3}{|c|}{ Session 2: Role of Lubrication in Micropitting and its Control } \\
\hline 4:00 p.m. & Rolling Contact Fatigue (RCF)—Lubricant Effects & $\begin{array}{l}\text { Martin Webster, } \\
\text { ExxonMobil }\end{array}$ \\
\hline \multicolumn{3}{|c|}{ Day 2: April 16, 2009} \\
\hline 8:30 a.m. & Influence of Lubricant Chemistry on Micropitting & Andy Olver \\
\hline 10:20 a.m. & Gear Testing to Aid the Understanding of Micropitting & $\begin{array}{l}\text { Brian Shaw, } \\
\text { University of } \\
\text { Newcastle }\end{array}$ \\
\hline \multicolumn{3}{|c|}{ Session 3: Laboratory and Field Test Methods for Micropitting Studies } \\
\hline 11:00 a.m. & $\begin{array}{l}\text { Analytical and Experimental Methods for Micropitting } \\
\text { Research }\end{array}$ & $\begin{array}{l}\text { Robert Errichello and } \\
\text { Andy Olver }\end{array}$ \\
\hline 11:30 a.m. & Systematic Tribology Test Methods for Micropitting & $\begin{array}{l}\text { Vern Wedeven, } \\
\text { Wedeven Associates }\end{array}$ \\
\hline \multicolumn{3}{|c|}{ Session 4: Concluding Discussion and R\&D Roadmap Development } \\
\hline 1:30 p.m. & How to Prevent Micropitting & Robert Errichello \\
\hline 2:00 p.m. & Concluding Discussion & All Attendees \\
\hline 4:00 p.m. & Tour of National Wind Technology Center & Jim Johnson, NREL \\
\hline
\end{tabular}

During the concluding discussion in Session 4, the attendees explored the following topics, listed here by session:

- Session 1:

- What is not known about micropitting?

- Who other than the attendees is doing leading research on the subject?

- Is there general agreement in the field on the knowns and the unknowns of micropitting? 
- Session 2:

- What scale of testing is most helpful in solving micropitting issues in wind turbine components?

- Is a new type of test rig needed for full-sized bearings?

○ Who might design/build it?

- Session 3:

- What do applications engineers need to know about micropitting and how can that information be communicated? What are the deficiencies of current guidelines and standards?

- What basic research issues remain in order to enable more informed solutions to micropitting problems?

○ How should the research needs be prioritized: Improved mechanical design tools? Better materials or surface treatments? Improved lubricants or lubrication systems? Better test methods?

In addition, the participants discussed possible recommendations for research by the U.S. Department of Energy (DOE) on preventing micropitting in wind turbine gearboxes:

- Form advisory committee.

- Recommend research for DOE.

- Suggest possible laboratory testing methods (disk machine?).

- Establish baseline (representative) micropitting conditions.

- Test coatings and lubricants.

- Design/build/test on full-scale laboratory bearing test rig.

- Repeat coatings/lubricants tests.

- Specify field tests.

Finally, the attendees toured the National Wind Technology Center (NWTC) before adjourning the workshop.

The synthesis and critical evaluation of the information presented here revealed a complex challenge for the wind power community and highlighted the need for additional research in multidisciplinary areas: mechanical engineering, contact mechanics, component design, lubrication, condition monitoring, basic tribology, and materials science. 


\subsection{Summary of Presentations}

In this section, we group summaries of the workshop presentations under the following categories: (1) micropitting review; (2) lubricant effects on micropitting; (3) characterization and testing; (4) modeling; and (5) prevention. Note that, by design, these major groupings do not necessarily align with the workshop's agenda. Instead, they are intended for ease of use and reference in this recap report.

\subsection{Micropitting Review}

\subsubsection{State of the Art: Micropitting}

Robert Errichello, GEARTECH

\section{Morphology of Micropitting}

Understanding the morphology of micropitting is important because it differs depending on the manufactured surface texture produced by different grinding machines.

Scanning electron microscopy (SEM) shows that the floor of a micropit crater slopes gently downward from its origin at the tooth surface. The floor has a rough surface typical of that caused by ductile fatigue crack propagation. A featheredge forms at the back of the crater because of plastic flow of material over the crater rim. The featheredge appears white in SEM when it becomes charged with electrons. Material surrounding a micropit generally appears smooth and featureless unless abraded.

\section{Mechanism of Micropitting}

Micropitting occurs under mixed-film elastohydrodynamic lubrication (EHL) where oil film thickness is of the same order as surface roughness average $(\mathrm{Ra})$ and load is borne by surface asperities and lubricant. When asperities carry a significant portion of load, collisions between asperities on opposing surfaces cause elastic or plastic deformation, depending on the severity of local loads. Micropitting experiments show that specific film thickness is a useful parameter for assessing the severity of asperity contact, but Chiu (1997) has shown that surface roughness has a stronger influence on micropitting life than does EHL film thickness.

In addition to contact stress caused by normal loading, sliding between gear teeth causes tractive forces that subject asperities to shear stresses. Tokuda (1977), Spikes (1986), and Akamatsu (1989) have shown that the first $10^{4}$ to $10^{6}$ cycles of stress occurring during run-in are an incubation period during which damage consists primarily of plastic deformation at asperities. Cyclic contact and shear stresses accumulate plastic deformation on asperities and at shallow depths below asperities. Plastic flow produces tensile residual stresses (Olver 1984; Chiu 1997), and with sufficient cycles, fatigue cracks initiate.

After incubation, micropits rapidly nucleate, grow, and coalesce. Microscopy shows a continuously cracked surface. Periodic inspection of tooth profiles with a gear inspection machine discloses a steady rate of surface deterioration. Damage can be extensive after 
only $10^{6}$ cycles. The length of the incubation period and the rate of surface deterioration depend on the relative hardness of the specimen and the mating components. Olver (1995) has shown that relative hardness and persistent roughness are the principal parameters that determine the severity of micropitting damage.

\section{Significance of Micropitting}

Micropitting degrades gear tooth accuracy when it causes nonuniform wear. It may preferentially attack pinion dedenda and cause disparity between base pitches of the pinion and gear. Consequently, spacing errors can cause noisy gears and create dynamic loads that can lead to gear tooth failure.

Micropitting can alter the manufactured profiles of rollers and raceways in a rolling element bearing and lead to a geometric stress concentration that results in macropitting at the ends of the rollers and edges of the raceways.

Failure analyses show that micropitting is frequently a primary failure mode responsible for initiating other secondary failure modes such as macropitting, scuffing, bending fatigue, and polishing.

\section{Effects of Surface Coatings}

Sacrificial coatings such as manganese phosphate, copper, or silver help limit wear to mild adhesion during run-in and protect the surfaces during the critical run-in (incubation) period.

\section{Effects of Lubricant Type}

Polyalkyleneglycol (PAG) lubricants have significantly thicker EHL films than polyalphaolefin (PAO) and mineral (MIN) lubricants over most of the temperature range in which wind turbine gearboxes operate, and PAG lubricants have demonstrated very good micropitting resistance. PAO and MIN lubricants have essentially the same EHL film thickness for $70^{\circ}-90^{\circ} \mathrm{C}$, and both $\mathrm{PAO}$ and MIN lubricants can have good micropitting resistance. Differences in performance of PAO and MIN lubricants depend primarily on their additives.

\section{Presentation Summary}

- Low specific film thickness promotes micropitting.

- Asperities and oil film share load.

- Asperities deform and crack during run-in.

- Micropit incubation occurs early.

- After incubation, micropitting grows.

- Micropitting degrades accuracy.

- Micropitting can escalate into other failure modes.

- Coatings act as solid-film lubricant and protect surfaces during run-in. 
- PAG lubricants have thick EHL films and very good micropitting resistance.

- PAO and MIN lubricants have similar EHL films and can have good micropitting resistance depending on their additives.

\subsubsection{Micropitting of Rolling Element Bearings}

Michael Kotzalas, Timken Company

The morphology of micropitting in gears and bearings can be different, and crack propagation rate can be slower in bearings because there is less sliding in bearings. Under high sliding, cracks are oriented in the same direction and propagate opposite to the sliding direction. Under low sliding, the cracks are randomly oriented.

\section{Background: Micropitting in Gears}

- Surfaces

- Finishing process creates "lay" perpendicular to contact motion.

- Gear surfaces have larger tractive forces than bearings.

- Gear surfaces have larger surface roughness than bearings.

- Damage mechanism

- Cracks form quickly under asperities because of plastic deformation.

- Cracks quickly propagate owing to surface lay and sliding.

\section{Background: Micropitting in Bearings}

- Surfaces

- Finishing process creates "lay" parallel to contact motion.

- Bearings surfaces have smaller tractive forces than gears.

- Bearings surfaces have smaller surface roughness than gears.

- Damage mechanism

- Cracks form over time under asperities because of plastic deformation.

- Cracks slowly propagate because of surface lay and lack of sliding.

\section{Application Issues}

- Debris damage

○ Debris dents cause raised shoulders.

- Raised shoulders act as stress concentrators and reduce oil film thickness.

○ Micropits initiate at shoulders.

- Tractive forces-microslip 
$\circ$ Wind turbine bearings must be designed to accommodate high loads. This requires rollers with high end-relief that may lead to microslip under lighter loads, which may promote micropitting.

○ Roller skewing increases microslip.

○ Microslip has relatively small tractive forces.

- Tractive forces - gross slip

- Lighter loads and high speeds cause inertial forces that are large relative to the normal loads and smaller load zones that lead to sliding between rollers and inner raceway.

- Smaller load zones create higher roller-to-cage loads that promote slip.

○ Full-complement bearings have low film thickness and high sliding velocity between rollers, which often leads to scuffing.

○ Scuffing damage may initiate micropitting.

- Edge stresses

- Heavy concentrated load owing to misalignment, improper roller or raceway crowning, or extreme loading may promote micropitting.

- Lubricant effects

- Lubricant additives can be detrimental to fatigue life. Experiments have shown that additives can attack weak points on bearing surfaces.

- Specific film thickness calculations should use a modified lambda ratio as described by Moyer (1990).

- Surface coatings

- Surface treatments such as black oxide and phosphate are sacrificial coatings that facilitate run-in and help prevent scuffing and micropitting.

\section{Presentation Summary}

- Gears have a surface lay perpendicular to the contact motion, large tractive forces, and relatively rough surfaces, whereas bearings have a surface lay parallel to contact motion, smaller tractive forces, and smoother surfaces. These differences may explain differences in micropitting morphology and crack propagation rate.

- In gears, cracks are oriented in the same direction and propagate opposite to the sliding direction, whereas in bearings cracks are randomly oriented.

- Debris dents cause raised shoulders that act as stress concentrators and reduce oil film thickness. Micropits initiate at shoulders.

- Wind turbine bearings must be designed to accommodate high loads. This requires rollers with high end relief that may lead to microslip under lighter loads, which may promote micropitting. 
- High speed, light loads, centrifugal forces, and full-complement bearings may cause gross slip and promote micropitting.

- Heavy concentrated load resulting from misalignment, improper roller or raceway crowning, or extreme loading may promote micropitting.

- Certain lubricant additives can be detrimental to fatigue life. Experiments have shown that additives can attack weak points on bearing surfaces.

- Specific film thickness calculations should use a modified lambda ratio as described by Moyer (1990).

- Surface treatments such as black oxide and phosphate are sacrificial coatings that facilitate run-in and help prevent scuffing and micropitting.

\subsection{Lubricant Effects on Micropitting}

\subsubsection{Fundamentals of Tribochemistry, Wear, and Surface Property Control} Stephen Hsu, George Washington University

In the hydrodynamic lubrication (HL) regime, a continuous fluid film supports $100 \%$ of the load and separates opposing surfaces. Surface roughness has little or no influence. Lubricant film thickness depends on the EHL inlet conditions of speed, geometry, and fluid viscosity.

In EHL lubrication, the lubricant film and asperities share load. Flash temperatures from asperity contacts influence viscosity around asperities, and chemical reactions between the lubricant and the surfaces may occur.

Under boundary lubrication (BL), contacting asperities either fully or mostly support the load. Elastic and plastic deformation occurs at asperities, and chemical reactions between the lubricant and metal surfaces create surface films that protect the surfaces by preferentially wearing the surface films. With high loads, failure modes can include plastic deformation, scuffing, abrasion, and fatigue. To protect surfaces, chemical films must provide:

- Adhesion with surfaces.

- Cohesive strength to resist shear and abrasion.

- Load capacity to support normal load.

- Thickness and hardness sufficient to support a significant portion of the load.

Chemical Reactions

The base oil and its polar constituents form the following:

- Oxidation products.

- Acids. 
- Adsorption films.

- Hydrogen abstraction to form conjugated double bonds.

- Condensation to form high molecular-weight organometallic compounds (friction polymers).

Lubricant additives function by the following mechanisms:

- Thermal decomposition.

- Surface-active species.

- Preferential adsorption.

- Thermally induced bonding.

- Formation of an inorganic reinforcing layer.

Additives need soft, "movable" friction polymers from base oil reaction products to work properly.

A detailed collision by collision experiment using two $3 \mathrm{~mm}$ diameter steel spheres was done to examine the surface and subsurface damage mode under several conditions: unlubricated, lubricated with paraffins, and paraffins plus antiwear additives. A high speed video camera mounted on the side captured the shear motion and the resulting shape. The $\mathrm{x}, \mathrm{y}, \mathrm{z}$ forces were measured by force transducers. After each collision, the surface damage was photographed, and some experiments were repeated after the same number of collisions, but the sample was cross-sectioned to show the substrate phenomena. Results showed the metal subsurface grains deformed to align with the principal component shear stresses, forming slip lines. Each collision added some more shear strain and the strain accumulated over time, resulting in an increasing angle of the slip lines toward the horizontal plane. Near the surface, the strain angle increased and permanent shear deformation and wear occurred. After 250 to 500 collisions, depending on the lubrication condition, micropits appeared on the surface.

The lubricant and additive tend to prolong the induction time by redistributing the stresses over a larger area, hence reducing the stress intensities and prolonging the induction time to micropitting. The additives do not change the basic process or the mechanism.

\section{Presentation Summary}

Micropitting depends on:

- Plastic deformation of surface asperities.

- Lubricant ability to form thick boundary layers.

- Chemical tribofilm's ability to flow with deformation. 
Micropitting in gears is related to cumulative shear strain in asperities under cyclic loading. Prevention methods include the following:

- Change materials to increase strength.

- Change design to lower stress intensity.

- Add large molecules with more branched chains to induce thicker fluid films.

- Introduce surface textures to promote thicker films.

\subsubsection{Influence of Lubricant Chemistry on Micropitting}

Andy Olver, Imperial College, UK

Experiments on a disk test rig show that zinc dialkyl-dithio-phosphate (ZDDP) antiwear (AW) additives can suppress run-in and promote micropitting. Other tests show that micropitting damage encountered with ZDDP additive can be greatly reduced when molybdenum bis-diethylhexyl dithio-carbamate (MoDTC) additive is also present.

Transmission electron microscopy (TEM) and X-ray photoelectron spectroscopy (XPS) show that ZDDP+MoDTC AW additive forms a tribofilm with an outer surface that is markedly smoother than the steel substrate.

\section{Presentation Summary}

- AW additives suppress mild wear.

- AW additives slow the run-in process.

- AW additives cause persistent roughness and persistently high local stresses.

- Persistently high local stresses cause micropitting.

- Different AW additives behave similarly. When a molybdenum friction modifier is added to AW oil, however, initial micropitting damage gradually disappeared with continued running. This combination of additive types seems to be a key to combining wear protection and micropitting resistance.

- It is postulated that improved micropitting resistance, obtained with ZDDP+MoDTC additive, is attributable to reduced asperity friction.

\subsubsection{Rolling Contact Fatigue (RCF): Lubricant Effects}

Martin Webster, ExxonMobil

Gear Oil Formulators

Gear oil formulators must achieve an overall best balance of competing properties:

- Antiwear/antiscuff.

- Macropitting/micropitting resistance.

- Oxidation resistance.

- Filterability. 
- Demulsibility.

- Rust/corrosion resistance.

- Foam control.

- Deposit control.

- Seal/material compatibility.

Rolling Contact Fatigue

Properties that affect RCF include:

- Viscosity

○ Affects EHL film thickness.

- Depends on molecular structure of lubricant base stock.

- EHL traction

- Affects friction transmitted across the lubricant film.

- Depends on molecular structure of lubricant base stock.

- Subjects surface cracks to tensile stress at the EHL inlet and promotes hydraulic propagation of fatigue cracks.

- The central portion of the EHL film determines the tractive forces.

- EHL film thickness

○ Increased specific film thickness reduces micropitting.

○ Increased specific film thickness increases bearing life.

- EHL film thickness is determined by the conditions at the inlet, including geometry, speed, and temperature of the bodies.

- Chemical effects

- Mechanisms not well understood and no model exists.

- Experimental data are available for limited classes of lubricants.

- Industrial MIN gear oils give significantly shorter bearing lives than MIN base stock without additives.

- Industrial PAO gear oils have bearing L10 lives similar to industrial MIN oils, but longer L50 lives.

- Industrial PAO circulating oils with phosphorus-only additives give significantly longer bearing lives than industrial MIN and PAO gear oils.

- Automotive rear axle oils all give significantly shorter bearing lives than a nonadditized base stock.

- Water contamination significantly shortens bearing life. For example, increasing water concentration from $50 \mathrm{ppm}$ to $500 \mathrm{ppm}$ reduces L10 life by a factor of three. 


\section{Bearing Life Adjustment Factors for Common Lubricants}

The ASME design guide (ASME 2003) titled "Life Ratings for Modern Rolling Bearings" gives an average life adjustment factor of 0.8 for hydraulic oils, AW roll bearing oils, turbine oils, AW circulating oils, MIN gear oils, and ATF automotive oils. The only oils with life adjustment factors greater than 1.0 are roll bearing oils without AW additives, circulating oils without AW additives, synthetic AW gear oils, and aviation turbine oils.

\section{Presentation Summary}

- Lubricant base stock affects EHL film thickness and surface tractive forces.

- Increased specific film thickness reduces micropitting.

- Increased specific film thickness increases bearing life.

- Lubricant additives affect bearing fatigue lives either negatively or positively, depending on additive composition.

- Water contamination significantly shortens bearing life.

\subsection{Characterization and Testing}

\subsubsection{Helical versus Spur Gears}

\section{Robert Errichello, GEARTECH}

Spur gears are not a good choice for achieving high repeatability in tribology tests because they have complex dynamics and are overly sensitive to changes in their tooth profiles. This makes it difficult to control test parameters and leads to wide scatter in test results. Helical gears operate much more smoothly, are less sensitive to profile changes, and have less scatter in test results.

\section{Spur and Helical Hertzian Fatigue}

- Hertzian fatigue is the same for both types of gears, but size-for-size helical gears have higher resistance to Hertzian fatigue.

- Spur gears suffer more because of loss of profile accuracy because micropitting destroys base pitch.

- Axial pitch may remain accurate on helical gears despite micropitting.

- Tip relief is critical on spur gears and much less important on helical gears.

Spur gear dynamic behavior is strange. Spur gear mesh stiffness is nonlinear and transmission error (TE) is strongly load dependent. Helical gear mesh stiffness has less variation and lower TE. Spur gears have more areas of resonance caused by superharmonics and instabilities.

Spur gears are poor test gears because: 
- Wear degrades profiles, changes TE, and increases dynamic tooth loads.

- Nonlinear mesh stiffness promotes resonance.

- Test rig locked torque may vary $15 \%$ under slow roll.

- Debris is trapped between profiles.

- Bending fatigue is catastrophic.

- A dent at the Start-of-active-profile (SAP) promotes macropitting.

- Micropitting creates geometric stress concentration (GSC) macropits.

\subsubsection{Survey of Micropitting Research Work of Germany's FVA and Status of Work within ISO-WG 15 "Micropitting"}

Thomas Tobie, FZG-TU-Munich

The Forschungsvereinigung Antriebstechnik E.V. (FVA) research projects FVA 54/I+II (1977-1983) were performed to study micropitting and macropitting for different materials, lubricants, flank roughness, operating conditions, and other influences.

FVA 54/III+IV (1985-1992) tests were run at higher speed. Tests were conducted for different gear geometry, lubricants, flank roughness, operating conditions, and other influences such as burnishing, copper plating, and phosphate coatings.

FVA research project 259/I (1994-1998) investigated the influence of gear geometry and gear size on micropitting.

FVA research projects 259/II+III (1998-2001) investigated the influence of gear tooth grinding process.

FVA research projects 286/I+II+III (1998-2009) investigated the influence of large gears.

FVA research projects 289/I+II (1995-2003) studied the influence of tribological layers.

FVA research project 459/I (2004-2006) studied the influence of micropitting on macropitting resistance.

FVA research project 482/I (2005-2007) investigated micropitting and macropitting behavior of low-speed external and internal gears.

FVA research project 488/I (2006-2008) studied the influence of water contamination on micropitting resistance.

Based on the theoretical and experimental results of these research projects, researchers developed an advanced calculation model to calculate the risk of micropitting of gears and to estimate the expected profile deviations caused by micropitting. 
Since 2005, the ISO TC 60/SC 2/WG 15 Committee has been developing a standardized calculation method for assessing the micropitting risk for gears.

\section{Presentation Summary}

FVA research has shown that micropitting depends on many variables, and it influences several characteristics of gears. For example, micropitting:

- Depends on flank roughness.

- Depends on surface hardness.

- Is initiated primarily in flank areas with negative specific sliding.

- Depends on lubricant and specific film thickness.

- Depends on lubricant additives.

- Depends on oil inlet temperature.

- Depends on gear size.

- Depends on grinding process.

- Influences dynamic forces and noise.

- May influence macropitting resistance.

- Depends on the tribological layer, which is a function of the lubricant, temperature, and operating conditions.

- Depends on low speed and whether external or internal gears.

- Depends on the level of water contamination.

\subsubsection{Systematic Tribology Test Methods for Micropitting}

Vern Wedeven, Wedeven Associates

In the present context, systematic tribology is defined as developing and testing tribology technology as a system with interactive and multiple failure modes. Tribology testing must be tuned to the service hardware and state of lubrication. Key tribology parameters for linking tests with service performance are:

- Specific film thickness.

- Entraining velocity.

- Sliding velocity.

- Contact temperature.

- Contact stress.

- Traction coefficient.

\section{Micropitting in Gas Turbine Engines}

Micropitting is a significant life-limiting failure mode for main shaft ball bearings. Low specific film thickness with near pure-rolling conditions produces micropitting. 


\section{Root Causes of Micropitting in Aeropropulsion}

- Ultrathin films and high surface stresses (normal and tractive).

- Debris dents and surface defects as stress concentrators.

- Surface roughness (asperity peaks with high stress).

- Irregular surface geometry resulting from surface film wear protection and polishing wear.

\section{Debris Dents and Surface Flaws}

Micropitting initiates from raised shoulders associated with debris dents and other surface flaws such as abrasion scratches and scuffing furrows.

\section{Influence of Specific Sliding (Ratio of Sliding Velocity to Rolling Velocity)}

Micropitting decreases in severity as contact slip decreases, but it is also found at $0 \%$ slip (pure rolling). Exploratory tests show that specific film thickness and traction coefficient determine whether micropitting occurs. Therefore, all micropitting tests should include measurements of traction coefficient.

\section{Polishing Wear and Micropitting}

Micropitting can be initiated by unequal wear resulting from polishing in one area and wear protection by surface films in other areas. This phenomenon has been observed in ball bearings when micropitting formed at the crests of circumferential ridges that formed on the inner raceway. Polished valleys were found on either side of the ridges. Sulfide films were found on the ridges, whereas the highly polished valleys were free of sulfide films. It is postulated that the ridges form at points of true rolling where sulfide films protect the surfaces, and polishing wear removes the protective films and creates valleys on either side of the ridges in areas of Heathcote slip (slip that occurs because ball radii have varying velocity).

\section{Presentation Summary}

- Experience in aeropropulsion shows micropitting to be caused by low lambda ratio, surface defects, surface roughness, and irregular wear. Similar causes are expected in wind turbines.

- Initiation of micropitting and whether it propagates are critically linked to polishing wear at an asperity level and wear affecting the global geometry. Therefore, the material/oil chemical reaction and boundary lubrication are important.

- The mechanism of micropitting seems to be reasonably well understood, and micropitting resistance can be increased through improved design and manufacturing processes. Advanced lubrication and surface technologies for increased micropitting resistance, however, are needed. This needs to be an interdisciplinary and industry-wide team effort.

- Solutions to micropitting are likely to have negative effects on other performance attributes. Therefore, a systematic tribology approach is necessary. 


\subsubsection{Gear Testing to Aid the Understanding of Micropitting}

Brian Shaw, University of Newcastle

Experimental tests are necessary to study micropitting. Test rig development and testing methodologies must include mechanical design, metallurgical assessment, failure analysis, metrology, and condition monitoring.

Characteristics of Micropitting

- Can be found in all gear applications.

- Becoming more prevalent.

- Often regarded as secondary failure mode.

- Can increase noise and vibration.

- May escalate into macropitting, scuffing, and flank-initiated bending fatigue.

- Mechanism and root cause not well understood.

- Is a complex failure mode influenced by many variables.

Contributing Factors

- Material

- Composition.

- Quality (flaws such as grind temper).

- Heat treatment.

- Residual stress.

- Microstructure.

- Gear design

○ Macrogeometry.

○ Microgeometry.

- Specific sliding.

- Manufacturing process

$\circ$ Grinding.

$\circ$ Finishing.

○ Surface roughness.

- Accuracy.

- Flaws.

- Surface treatments

- Shot peening. 
○ Superfinishing.

$\circ$ Coatings.

- Operating conditions

○ Torque.

○ Speed.

- Lubrication (viscosity, additives).

- Temperature.

○ Duty cycle.

\section{Mechanism}

- Gear running changes near surface material properties.

- Localized plastic deformation at asperities changes residual stresses and transforms retained austenite.

- Micropits initiate at high asperities.

- Micropits coalesce until entire original surface is removed.

\section{Prevention}

- Improve surface finish. Superfinished gears have greatest resistance to micropitting.

- Avoid shot-peened gears because they have low micropitting resistance because of increased surface roughness. Grinding after shot-peening, however, improves micropitting resistance.

- Optimize gear design to minimize specific sliding and avoid edge stresses.

- Increase gear accuracy.

- Use lubricants with high micropitting resistance.

\section{Future Research Needs}

- Identify ideal material properties such as retained austenite and residual stress and any benefits from alloy choice and heat treatment method.

- Modify surfaces to obtain optimum surface texture and minimum friction.

- Develop lubricant additives that give adequate scuffing resistance and maximum micropitting resistance.

- Develop coatings to maximize micropitting resistance.

- Develop analytical models for investigating mechanisms for crack initiation and propagation.

Presentation Summary 
- With modern clean steels, Hertzian fatigue is dominated by micropitting rather than subsurface initiated macropitting.

- Asperity contact stresses are the root cause of micropitting.

- Micropitting is influenced by a complex interaction of many variables.

- Understanding micropitting is the key to improving performance.

- Research is needed to develop material properties, lubricant properties, and surface engineering to obtain gears and bearings with improved performance.

\subsubsection{Analytical and Experimental Methods for Micropitting Research}

Both disc test rigs and gear test rigs have their place for experimental investigation into micropitting. The choice of the test rig depends on the objectives of the test and on the advantages and disadvantages of the different test rigs.

Andy Olver, Imperial College

\section{Micropitting Test Objectives}

- Create micropitting under controlled conditions.

- Obtain reproducible parameters to indicate severity or progression of micropitting.

- Study effects of variables such as materials, lubricants, load, temperature, and surface finish.

- Understand the relationship of the test to any relevant service components.

Typical Problems with Micropitting Tests

- Tests take too long (and speeding up machine eliminates failure).

- Too much fluid is required.

- Wear changes the macrogeometry and roughness.

- Initial micropitting "fizzles out."

- Scuffing and macropitting occur instead of micropitting.

- Sliding causes uncertainty in film thickness because of thermal feedback.

- Wear affects dynamic loads.

- No micropitting occurs with viscous oils.

Test Rigs-A Comparison of Gear Testers with Disc-on-Disc Machines

- Advantages of gear testers

○ Representative of some gears.

- Allows direct investigation of gear geometry effects.

- Representative failure progression. 
- Wide range of contact conditions.

- Disadvantages of gear testers

○ Results not convincing for other components.

- Rapidly varying contact conditions.

○ Poor control of thermal and dynamic effects.

○ Very expensive test specimens.

- Long test time.

○ Large lubricant volume.

- Advantages of disc-type testers

- Close control of load, speed, and temperature.

- Precisely reproducible surface roughness.

- Much lower test time with multiple contact tester.

○ Precise wear depth measurement.

- Disadvantages of disc-type testers

- Not convincing for gear engineers.

○ Point contact fizzles out because of the decline in Hertzian stress.

- Test specimens still expensive and require careful finishing.

\subsection{Modeling}

\subsubsection{Micropitting, Micro-EHL, and Mixed Lubrication}

Ray Snidle, Cardiff University

EHL theory explains the generally successful operation of most types of gears. EHL has been less successful, however, in explaining and predicting failures of gear tooth contacts. There is an urgent need to develop a detailed understanding of "mixed" lubrication because this is the mode of lubrication in highly loaded gears. Greater emphasis needs to be given to initial plastic deformation in real, lubricated contacts.

A micro-EHL mathematical solver for Hertzian contacts must be capable of handling the following:

- Low lambda ratios (< unity).

- Thin films (10 nm).

- Transient condition (moving roughness).

- Real loads and speeds (rolling/sliding).

- Thermal effects. 
- Non-Newtonian lubricant properties.

\section{Presentation Summary}

- Transient micro-EHL analysis results are used to generate time histories of stress at each material point.

- Fatigue failure models of both critical plane (plane with most fatigue damage) and cumulative damage type give similar results for a particular rough surface.

- Calculated damage is greatest close to the surface.

- Calculated damage increases with sliding speed and decreases with increasing viscosity.

- Dry contact is significantly worse than lubricated contact from a calculated damage perspective.

A full, up-to-date list of papers published by the Cardiff group since 2001 is available, for example, at http://www.engin.cf.ac.uk/whoswho/profile.asp?RecordNo=69.

The Cardiff University's tribology Web site is at http://tribology.engineering.cf.ac.uk/.

\subsubsection{Modeling Micropitting: The CAT Model}

Andy Olver, Imperial College, on behalf of Caterpillar

The Caterpillar (CAT) theoretical model of rough-surface contact, developed by Ping Wang, Diann Hua, and Tom Beveridge (Caterpillar), and Emmanuel Laine, and Andy Olver (Imperial College), accounts for evolving roughness with time caused by mild wear and fatigue damage. The CAT model has the following features:

- Explicit three-dimensional description of both surfaces.

- Elastostatic model without lubricant mechanical properties.

- Model for gradual wear.

- Model for fatigue damage.

- Rules for material removal and shape change resulting from micropitting.

- Lubricant chemistry acts only by changing wear coefficient in the gradual wear model.

Flow Chart for the CAT Model

A. Input material properties, contact geometry, and operating conditions.

B. Calculate surface and subsurface stresses.

C. Calculate fatigue damage.

D. Calculate gradual wear.

E. Calculate modified surface.

F. Iterate A through E until surface change is small. 


\section{Presentation Summary}

The CAT model has achieved the following:

- Accounts for competing mechanisms of gradual wear and micropitting.

- Discriminates behaviors of different oils.

- Predicted wear depth agrees with experiments.

- Predicted surface change on counterface agrees with experiments.

- Agrees with experimental results that show antiwear additives suppress run-in and promote micropitting.

\subsection{Prevention}

\subsubsection{How to Prevent Micropitting}

Robert Errichello, GEARTECH

The following guidelines were developed from experiments and inspections of laboratory and industrial gears and from literature reviews. Not every measure will be achievable or applicable for a given application, but as many as possible should be implemented. The steps to prevent micropitting are as follows: maximize lambda, optimize gear geometry, optimize metallurgy, optimize lubricant properties, and protect surfaces during run-in.

Thick Oil Films Maximize Lambda

- Use highest practical viscosity.

- Use high speed.

- Use copious oil flow.

- Cool gear teeth.

- Use synthetic oil if tooth temperature $>80^{\circ} \mathrm{C}$.

Smooth Surfaces Maximize Lambda

- Avoid shot-peened gear teeth.

- Hone or polish teeth (or run-in against a hard, smooth master?).

- Make hardest gear as smooth as possible.

\section{Optimize Gear Geometry}

- Use aspect ratio (ratio of face width to pinion pitch diameter) $\mathrm{m}_{\mathrm{a}} \leq 1.0$.

- Use helical gears with face contact ratio (ratio of face width to axial pitch) $\mathrm{m}_{\mathrm{F}} \geq$ 2.0 .

- Use at least 20 teeth in the pinion.

- Use a nonhunting gear ratio.

- Minimize contact stress. 
- Use profile shift to minimize specific sliding.

- Use proper profile and helix modifications to obtain uniform load intensity without edge stresses.

- Avoid tip-to-root interference.

\section{Optimize Metallurgy}

- Maximize pinion hardness.

- Make pinion 2 Rockwell hardness (HRC) points harder than gear.

- Use $\approx 20 \%$ retained austenite.

\section{Optimize Lubricant Properties}

- Use oil with high micropitting resistance.

- Use oil with low traction coefficient.

- Use oil with high pressure-viscosity coefficient.

- Avoid oils with aggressive antiscuff additives.

- Avoid oils with viscosity index (VI) improvers.

- Keep oil cool, clean, and dry.

\section{Protect Surfaces during Run-in}

- Coat teeth with $\mathrm{Mn}-\mathrm{P}, \mathrm{Cu}$, or Ag.

- Use special oil (avoid AW additives).

- Use series of increasing loads and appropriate speeds.

- Limit each load duration based on wear particle generation rate.

- Prefilter oil to ISO 16/14/11 cleanliness per cleanliness code ISO 4406.

- Use a fine filter $(\leq 6 \mu \mathrm{m})$.

- Keep oil cool.

- Drain oil, flush, and change filter after run-in.

\section{Presentation Summary}

Methods to prevent micropitting are as follows:

- Maximize lambda.

- Optimize gear geometry.

- Optimize metallurgy.

- Optimize lubricant properties.

- Protect surfaces during run-in. 


\subsection{Summary and Conclusions}

At the open discussion session in Session 4, attendees discussed several topics that are also potential areas for future research and development and testing. They generally agreed on the need to conduct further research and tests of micropitting specific to wind turbines. The three main research components identified were gear, bearing, and lubricant. The long-term goal of these research and test efforts is to increase understanding of wind turbine micropitting phenomena and, subsequently, to standardize the relevant research and testing methods.

This section summarizes the points made during the open discussion.

\subsection{Possible Causes for Prevalence of Micropitting in Wind Turbines}

Micropitting is much more prominent in the wind industry than in other industries. It is present in both bearings and gears. The possible reasons identified include 1) much longer life expectation: commercialized large-scale wind turbines are designed to continuously run for 20 years, which is much longer than the typical life expectation for cars in automobile industry, and for equipment in most other industries; 2) unsteady wind: changes in amplitude, direction, and gust; 3) contamination in lubricants such as water, dirt, and wear debris; 4) low rpm and high loads: typical operating condition for the planetary stage of a wind turbine gearbox, leading to slow moving gears and bearings with low pitch line velocities, low oil film thickness, and high traction; and 5) high duty cycle. Further research and tests are thus necessary to fully understand micropitting phenomena in wind turbines and pinpoint the exact causes.

\subsection{Test Rigs and Strategy for Wind Turbine Micropitting}

Before a test is designed, the test objectives must be identified. There are typically two test objectives: 1) understanding micropitting phenomena specific to the application, and 2) finding solutions to solve the micropitting problems in wind turbine gearboxes. No matter which objective is targeted, an appropriate test rig is important for conducting meaningful and successful tests. Currently, there are three options: the Micropitting Rig (MPR) used by Imperial College, the Wedeven Associates Machine (WAM), and developing new test rigs. A specific test rig for wind turbines would be necessary because both MPR and WAM are not able to capture the simultaneous rotating and sliding actions occurring in gear sets. The rigs should be able to replicate the wind turbine field operational conditions, such as transients in loads, unsteady, high duty cycle, full lubrication system, typical contamination, and speeds, loads, and temperatures. When selecting test specimen, spur gears appear to be a bad choice, because the tooth profile characteristics change throughout the test. On the other hand, an accelerated life test needs to be designed and conducted to reflect the 20 years of wind turbine design life. Ultimately, wind turbine gearbox and bearing designers would use the test results. A proposal to the International Electrotechnical Commission IEC for a test standard for wind turbine micropitting is potentially achievable given the experience to be gained in these tests. 


\subsection{Standardized Test for Lubricant}

There is a large gap between lab and field tests for lubricant. FVA 54 has been used extensively as the standard micropitting test for wind turbine gearbox lubricant. FVA 54 tests cannot, however, fully represent wind turbine field conditions, and they should be used as an initial guideline instead of a final step for a micropitting test. The FVA 54 test needs to be carefully planned so that a broad range of machine operating conditions can be covered. The test also needs to be conducted intelligently, to avoid deceptive results on lubricants with poor micropitting resistance performance. A progressive test approach for lubricant test is identified as the appropriate way to go. Proposing a standardized test approach for wind turbine lubricant would be one goal of the research and test efforts identified at this workshop.

\subsection{Run-in Procedure for Wind Turbine Gearboxes}

Present wind turbine gearbox manufacturers typically conduct gearbox run-in based on fixed time intervals. The attendees recommend conducting the run-in based on particle generation rates; some gearbox manufacturers have already taken this approach. There are, however, some remaining questions: What particles should be looked at, ferrous, nonferrous from gears, bearings, or other components, and how large? Also during the run-in, the level of antiwear additives in the lubricant is low (if the run-in oil has no antiwear additives), which could lead to scuffing if the run-in process is not performed carefully. As a result, some guidelines have to be specified for running-in a wind turbine gearbox. To reduce the chances of scuffing, the load has to be stepped up gradually before the full load is applied. How many load steps are appropriate? Should speed be different than the wind turbine operating speed? What oil temperatures should the run-in use and how should they be correlated with the load? The present IEC/ISO draft standard for wind turbine gearboxes requires the same oil to be used during the run-in and normal operation. This conflicts with the approach of running with low or no antiwear additives for the run-in process of wind turbine gearboxes. What practice does the wind industry need to follow? Recommending to IEC a run-in procedure for wind turbine gearboxes is another goal of the research and test efforts identified at this workshop.

\subsection{Needs for Further Research and Testing}

Presentations at this workshop and the discussions they stimulated support the need for an integrated, interdisciplinary approach to micropitting avoidance. Both experimental work and modeling work are needed, and the latter requires better information on wind turbine gearbox forces, stresses, and transients. Clearly, not all of the types of loads and stresses imposed on gearbox components will result in micropitting, but under some circumstances, they could contribute to its onset.

Because the micropitting on gears differs in certain respects from that seen on bearings, different approaches to defining the testing requirements and research needs are indicated for gears and bearings. This finding is consistent with the systematic tribology approach presented by Wedeven. The interdisciplinary nature of micropitting, component design, and lubricant selection also supports the need to establish standardized methods to define the magnitude of micropitting problems, and to use consistent terminology to better communicate results across the disparate fields of failure root-cause analysis, component 
performance modeling, materials development, lubrication, and simulative experimentation.

Basic mechanisms responsible for micropitting have been proposed by several investigators, and the degree to which they are fully understood remains a subject of controversy in the tribology and mechanical engineering communities. If these mechanisms were indeed well understood, as some have asserted, then a proper research focus would be on selecting materials, surface treatments, lubricants, manufacturing methods, and bearing designs that reduce or eliminate the operation of those identified mechanisms. It may also be true that the causes of micropitting are better understood in some kinds of mechanical systems than in others. Increasing complexity of such interdisciplinary approaches results from the highly variable operating characteristics of wind turbines. Likewise, the similarities and differences between micropitting and other forms of surface damage must be better understood.

Scale effects in tribology enter the discussion because certain approaches to bearing and gear analysis treat mechanical components from a macroscopic point of view; that is, they look at geometrical arguments, stresses, and strains that are on the scale of dimensional drawings of production parts. Microcontact issues enter because of the size scale of the operative mechanisms that researchers associate with micropitting. These include attributes like surface roughness parameters, asperity and micropit sizes, and the dimensions of grains and inclusions within the gear and bearing alloys. As the presentations in the workshop indicated, the process of micropitting has also been associated with the state of the lubricating films that separate, or fail to separate, bearing surfaces. Lubricant formulations affect the composition and properties of such films and the surfaces on which they reside.

Several of the presentations alluded to the so-called lambda ratio or film parameter (i.e., the ratio of the fluid film thickness to composite surface roughness) to define the lubrication conditions between mating surfaces. Using this parameter for mechanistic studies has shortcomings because micropitting tends to reflect individual asperity interactions rather than the statistical average of the conditions within the larger nominal contact zone. Micropits may initiate and grow on a scale of a few micrometers but coalesce and spread to produce surface damage on a scale of millimeters or centimeters. Micro-EHL, mentioned by Snidle, is one approach to address this, but it is also important to recognize that only the arithmetic average roughness of many such features, not the shapes of the surface features, are directly reflected in the lambda ratio. In other words, two surfaces could have different asperity slopes, shapes, and lay but still have the same average roughness parameters that are used in the lambda ratio calculation. That subtlety may become important in determining which microfeatures could produce micropits and which might be more benign. Nevertheless, lambda does reflect the general tendency for solid contact to occur under a given set of liquid-lubricated operating conditions. Film thickness calculations require information such as pressure-viscosity coefficients of lubricants, which are not straightforward to measure and require specialized apparatus.

A basic understanding of mixed-lubrication and boundary lubrication regimes, in which lubricant film thickness and surface features have similar dimensions, becomes 
particularly challenging, but it is critical if micropitting is to be better understood. Presentations on the pros and cons of antiwear films (Olver) and the role of tribochemistry (Hsu) exemplify a need to develop lubricating approaches that facilitate run-in without truncating long-term bearing surface reliability.

Another recurrent topic of discussion was that of running-in (a.k.a. break-in, wear-in). Tribologists and bearing designers recognize its importance in avoiding "infant mortality failures" and in extending the useful service life of bearings, seals, and gears. Despite this recognition, there has been relatively little systematic research on the nature of running-in as a function of lubricant type, surface roughness, material combination, heat treatment, coating type, and so on. Although research in the former Soviet Union produced quite a number of papers on running-in (including at least one standard for run-in ability of materials), much of the research in the western literature seems to reside in proprietary reports or in the undocumented "art" of engineering. Technicians or manufacturers may apply a certain running-in method to new or rebuilt mechanical systems, but fail to document them fully. Even when running-in procedures are routinely applied to certain types of machinery, these may have been developed by trial and error, without a firm scientific rationale. Therefore, systematic studies of running-in and its effects on micropitting are indicated.

From a broader perspective, running-in is only a part of the challenging area of tribological transitions. These include wear-out and the response of mechanical systems to transient events. Translated to wind turbine gearboxes, such events include rapid accelerations or decelerations caused by gusting or by side loads from changes in the wind direction. Bearing manufacturers sometimes complain that their customers specify bearings using only steady-state operating conditions, but not the transients that are more typical of the actual turbine gearbox applications. In fact, transients may affect wear life more than steady-state operation. From that point of view, a better method to simulate the actual spectrum of loads and directions experienced by gearbox bearings is needed. There is a need to develop a multiaxial gearbox rolling element bearing test system that can apply standardized operational spectra typical of various wind farm locations (e.g., Midwest, offshore, desert). Designing such a testing system requires detailed operational data from instrumented turbine components.

Another issue was only briefly mentioned at the workshop, but it may have an effect on micropitting and wear of bearing components. That is the issue of fretting from superimposed vibrations on the contact area, either when the rotors are turning or when the system is at rest. High-frequency, low-amplitude slip between contacting surfaces can generate fine, powdery wear debris, and depending on conditions, the debris can clump or accumulate in surface pockets. Perhaps a study of the role of fretting on the initiation phase of micropitting is needed, but this type of research was not explicitly advocated at the workshop.

In formulating recommendations for future work, we must distinguish between basic and applied research in light of the need to move wind turbine technology forward. The history of technology has many examples of engineering and empirical approaches leading fundamental understanding of the reasons how and why certain strategies and 
designs work. Some of the issues discussed in the workshop are fundamental: How do lubricants work on a nano-scale level? How do dislocation pile-ups and lattice defects created at the subasperity level coalesce into microcracks that eventually lead to micropits? Some issues are highly applied: What kind of finishing process is required for certain types of bearings? What running-in method should be applied to condition a new gearbox? What is the minimum inspection interval? What kinds of sensors should be used to monitor bearing health?

Given that there are still some unknowns in the technical community's understanding of micropitting, Table 3-1 presents a summary of research needs. It has been reviewed by the organizers and speakers for content, but does not necessarily represent a unanimous agreement on what needs to be done. No attempt was made to list these items in order of priority. Several involve standardization. Because a number of contributors have expressed these ideas, they have not been ascribed to a particular person or organization. Furthermore, considering the limited attendance at the workshop, it is possible that additional micropitting research needs have been overlooked.

Table 3-1. Research Needs in Micropitting

\begin{tabular}{|c|c|c|}
\hline Item & Subject & Description \\
\hline$A$ & $\begin{array}{l}\text { Quantification of } \\
\text { micropitting damage }\end{array}$ & $\begin{array}{l}\text { Need a standardized method to quantify the degree of } \\
\text { micropitting damage observed on contact surfaces. This will } \\
\text { help diagnose the severity of field failures, assess the } \\
\text { evolution of surface damage, and help in the correlation of } \\
\text { laboratory test data with field observations. }\end{array}$ \\
\hline$B$ & $\begin{array}{l}\text { Employment of a } \\
\text { standardized } \\
\text { 'systematic tribology' } \\
\text { approach to } \\
\text { characterize bearings } \\
\text { and gear assemblies } \\
\text { that are prone to } \\
\text { micropitting }\end{array}$ & $\begin{array}{l}\text { Define the gearbox components characteristics in ways that } \\
\text { allow their tribological characteristics to be specified. This } \\
\text { includes obtaining a better understanding of load histories } \\
\text { and transients that can affect gear and bearing life. }\end{array}$ \\
\hline $\mathrm{C}$ & $\begin{array}{l}\text { Identification of } \\
\text { standard test methods } \\
\text { that can used to } \\
\text { generate micropitting } \\
\text { damage that simulates } \\
\text { field observations }\end{array}$ & $\begin{array}{l}\text { Allow standardization of laboratory-scale tests to be used to } \\
\text { cost-effectively and accurately screen lubricants, surface } \\
\text { treatments, and coatings for resistance to micropitting. }\end{array}$ \\
\hline $\mathrm{D}$ & $\begin{array}{l}\text { Improved gearbox } \\
\text { damage sensors }\end{array}$ & $\begin{array}{l}\text { Identify condition monitoring strategies that can sensitively } \\
\text { detect the presence of micropitting in operating gearboxes. } \\
\text { Alternatively develop methods to detect the symptoms of } \\
\text { micropitting, even if surfaces cannot be observed directly. }\end{array}$ \\
\hline$E$ & $\begin{array}{l}\text { Hydrogen } \\
\text { embrittlement studies } \\
\text { of gear and bearing } \\
\text { alloys }\end{array}$ & $\begin{array}{l}\text { Determine whether or not hydrogen embrittlement is a factor } \\
\text { in micropitting initiation. }\end{array}$ \\
\hline $\mathrm{F}$ & Run-in-ability studies & $\begin{array}{l}\text { Understand the asperity-level changes that occur during } \\
\text { run-in that could lead to micropitting using various lubricants } \\
\text { and surface treatment approaches. Determine the optimum } \\
\text { run-in lubricant, test parameters, and run-in procedure to } \\
\text { maximize resistance to micropitting. Determine condition } \\
\text { monitoring techniques necessary for controlling a proper }\end{array}$ \\
\hline
\end{tabular}




\begin{tabular}{|c|c|c|}
\hline & & run-in. \\
\hline G & $\begin{array}{l}\text { Material alloy, heat } \\
\text { treatment, and surface } \\
\text { treatment selection } \\
\text { strategies }\end{array}$ & $\begin{array}{l}\text { Using established micropitting test methods, establish a set } \\
\text { of material (alloy, heat treatment, and surface treatment) } \\
\text { selection rules to help designers avoid micropitting. This } \\
\text { may need to be part of a suite of tests to ensure that the } \\
\text { approaches used to reduce micropitting do not induce some } \\
\text { other form of surface damage, like abrasion, macropitting, } \\
\text { or scuffing. Determine the differences of through-hardened } \\
\text { bearing steels and case hardened gear and bearing steels } \\
\text { on micropitting resistance. }\end{array}$ \\
\hline $\mathrm{H}$ & $\begin{array}{l}\text { Wear-corrosion } \\
\text { synergy }\end{array}$ & $\begin{array}{l}\text { Determine if the presence of corrosive agents such as water } \\
\text { or acidic species in lubricants initiates or accelerates } \\
\text { micropitting beyond that which occurs by mechanical factors } \\
\text { alone. Resolve whether antiwear and antiscuff additives are } \\
\text { beneficial or detrimental to micropitting resistance. }\end{array}$ \\
\hline I & $\begin{array}{l}\text { Micropitting } \\
\text { morphology studies }\end{array}$ & $\begin{array}{l}\text { Determine the effects of percent slip in the characteristics of } \\
\text { micropits. This would differentiate the morphology of } \\
\text { micropits in bearings from that in gears, where slip tends to } \\
\text { be greater. Determine the influence of load magnitude and } \\
\text { load transients on slip in bearings and influence on } \\
\text { micropitting resistance. }\end{array}$ \\
\hline $\mathrm{J}$ & Manufacturing studies & $\begin{array}{l}\text { Determine the influence that various grinding machines } \\
\text { have on surface topography of gear teeth and rolling } \\
\text { element bearing surfaces and establish the degree (cost) of } \\
\text { surface finishing required to reduce the incidence of } \\
\text { micropitting in materials that vary in composition, hardness, } \\
\text { and heat treatment. Determine the influence of grind temper } \\
\text { on micropitting. }\end{array}$ \\
\hline $\mathrm{K}$ & Gearbox lubricant data & $\begin{array}{l}\text { Film thickness calculations require lubricant property data, } \\
\text { some of which is not always readily available to modelers. } \\
\text { Data such as pressure-viscosity coefficients for gearbox } \\
\text { lubricants need to be obtained and made more widely } \\
\text { available. }\end{array}$ \\
\hline $\mathrm{L}$ & Lubricant aging studies & $\begin{array}{l}\text { Changes in lubricity, antiwear characteristics, and } \\
\text { corrosiveness of lubricants subjected to aging in the field } \\
\text { need to be better characterized. At what point these } \\
\text { changes can lead to micropitting needs to be better } \\
\text { established. }\end{array}$ \\
\hline $\bar{M}$ & $\begin{array}{l}\text { Solid contaminant } \\
\text { influence }\end{array}$ & $\begin{array}{l}\text { Determine the influence of solid contaminants on } \\
\text { micropitting. Establish required oil cleanliness for wind } \\
\text { turbine gearboxes. }\end{array}$ \\
\hline $\mathrm{N}$ & $\begin{array}{l}\text { Hunting vs. nonhunting } \\
\text { gear ratio }\end{array}$ & $\begin{array}{l}\text { Determine whether wind turbine gears should have hunting } \\
\text { or nonhunting gear ratios to maximize micropitting } \\
\text { resistance. }\end{array}$ \\
\hline $\mathrm{O}$ & $\begin{array}{l}\text { Gear and bearing } \\
\text { rating standard for } \\
\text { micropitting risk }\end{array}$ & $\begin{array}{l}\text { Develop a rating standard for calculating the risk of } \\
\text { micropitting for gears and rolling element bearings. }\end{array}$ \\
\hline$P$ & $\begin{array}{l}\text { Bearing rating } \\
\text { standard }\end{array}$ & $\begin{array}{l}\text { Modify DIN ISO } 281 \text { to include the influence of micropitting } \\
\text { on calculated bearing life. }\end{array}$ \\
\hline
\end{tabular}


Footnote to Table 3-1: the letters in the first column are intended to facilitate communications regarding items in the table. 


\subsection{Bibliography}

Akamatsu, Y. "Peeling Damage Due to Rolling Contact Fatigue." SAE Paper No. 891909; Warrendale, PA: SAE, 1989; pp. 1-7.

ANSI/AGMA (American National Standards Institute and American Gear Manufacturers Association). Appearance of Gear Teeth- Terminology of Wear and Failure. AGMA 1010-E95. Alexandria, VA: AGMA, 1995; pp. 1-40.

ANSI/AGMA/AWEA (American National Standards Institute and American Gear Manufacturers Association and American Wind Energy Association). Standard for Design and Specification of Gearboxes for Wind Turbines. ANSI/AGMA/AWEA 6006-A03. Alexandria, VA: AGMA, 2003; pp. 1-94.

Ariura, Y.; Ueno, T.; Nakanishi, T. "An Investigation of Surface Failure of SurfaceHardened Gears by Scanning Electron Microscopy Observations." Wear; Vol. 87, 1983; pp. 305-316.

ASME (American Society of Mechanical Engineers). Life Ratings for Modern Rolling Bearings- A Design Guide for the Application of International Standard ISO 281/2. ASME TRIB-Vol. 14. ASME, 2003; pp. 1-91.

Bailey, D.M.; Sayles, R.S. "Effect of Roughness and Sliding Friction on Contact Stresses." J. Tribol.-T. ASME; Vol. 13, 1991; pp. 729-738.

Benyajati, C.; Olver, A.V.; Hamer, C.J. "An Experimental Study of Micropitting Using a New Miniature Test-Rig." Proc. 30th Leeds-Lyon Symp. on Tribology; 2003; pp. 601-610.

Benyajati, C.; Olver, A.V. "The Effect of a ZnDTP Antiwear Additive on the Micropitting Resistance of Carburized Steel Rollers.” AGMA Paper No. 04FTM6. Alexandria, VA: AGMA, 2004; pp. 1-10.

Berthe, D.; Flamand, L.; Foucher, D.; Godet, M. "Micropitting in Hertzian Contacts." J. Lubric. Tech.-T. ASME; Vol. 102, 1980; pp. 478-489.

Breen, D.H. "Physical and Analytical Modeling of Contact Fatigue Pits from Rolling/Sliding Tests." AGMA Paper No. 87FTM8. Alexandria, VA: AGMA, 1987; pp. 1-18.

Brimble, K.; Atkins, I.; Blencoe, K.; Aylott, C.; Shaw, B.A. "A Comparison of Micropitting Performance of Identical Oils Using Standard FZG Test Gears and Helical Test Gears." Paper 8 in Proc. British Gear Association Annual Congress, Drives and Controls Conference; Croydon, Surrey, UK: Kamtech Publishing, March 2001.

Bull, S.J.; Evans, J.T.; Shaw, B.A.; Hoffman, D.A. "The Effects of White Layer on Micropitting and Surface Contact Fatigue Failure of Nitrided Gears." Proc. IMechE J, J. Engineering Tribol.; Vol. 213, 1999; pp. 305-313.

Cardis, A.B.; Webster, M.N. “Gear Oil Micropitting Evaluation.” AGMA Paper No. 99FTM4. Alexandria, VA: AGMA, 1999; pp. 1-16. 
Cheng, W. "A New Roughness Parameter Including Hardness and Contact Frequency Effects on Lubricated Rolling/Sliding Wear.” Tribol. T.; Vol. 40, No. 3, 1997; pp. 486-492.

Chiu, Y.P. "The Mechanism of Bearing Surface Fatigue-Experiments and Theories." Tribol. T.; Vol. 40, No. 4, 1997; pp. 658-666.

Elcoate, C.D.; Evans, H.P.; Hughes, T.G.; Snidle, R.W. "Transient

Elastohydrodynamic Analysis of Rough Surfaces Using a Novel Coupled Differential Deflection Method." Proc. IMechE, Part J, J. Engineering Tribol.; ISSN 1350-6501. Vol. 215, 2001; pp. 319-337.

Epstein, D.; Keer, L.M.; Wang, Q.J.; Cheng, H.S.; Zhu, D. "Effect of Surface Topography on Contact Fatigue in Mixed Lubrication." Tribol. T.; Vol. 46, No. 4, 2003; pp. 506-513.

Errichello, R. "Friction, Lubrication, and Wear of Gears." ASM Handbook; Vol. 18, Oct. 1992; pp. 535-545.

Errichello, R. "Photography of Gear Failures." Gear Technol.; Vol. 11, No. 2, March/April 1994, pp. 43-46.

Errichello, R.; Muller, J. "Oil Cleanliness in Wind Turbine Gearboxes.” Machinery Lubric.; Vol. 2, No. 4, July/Aug. 2002; pp. 34-40.

Errichello, R. "Selecting and Applying Lubricants to Avoid Micropitting of Gear Teeth.” Machinery Lubric.; Vol. 2, No. 6, Nov./Dec. 2002; pp. 30-36.

Errichello, R. "Selecting Oils with High Pressure-Viscosity Coefficient." Machinery Lubric.; Vol. 4, No. 2, March/April 2004; pp. 48-52.

Errichello, R. "Micropitting of Gear Teeth-A Review of the Literature, Description of Morphology, Mechanism, and Significance, and Guidelines for Prevention." Unpublished manuscript.

Evans, H.P.; Tao, J.; Hughes, T.G.; Snidle, R.W. "Effect of Roughness on Elastohydrodynamic Lubricant Films in Gear Tooth Contacts." Proc. British Gear Association Annual Congress, Drives and Controls Conference; ISBN: 1-901672-492. Croydon, Surrey, UK: Kamtech Publishing, 2001; pp. 27-32.

Evans, H.P.; Snidle, R.W.; Sharif, K.J. "Deterministic Mixed Lubrication Modelling Using Roughness Measurements in Gear Applications." Presented at the 13th Nordic Symposium on Tribology (NORDTRIB 2008) and accepted for publication in Tribol. Int.; (in press).

Faure, L. "Micro Surface Damages on Tooth Flanks of Carburized Gears." AGMA Paper No. 88FTM4. Alexandria, VA: AGMA, 1988; pp. 1-7.

Flamand, L.; Berthe, D. "A Brief Discussion of Different Forms of Wear Observed in Hertzian Contacts at Low Slide/Roll Ratios." Surface Roughness Effects in Lubrication, Proc. 4th Leeds-Lyon Symp., Lyon, 1977, Mechanical Engineering Publications, London, 1978, pp. 239-242.

FVA Information Sheet "Micropitting," No. 54/7, July, 1993, Forschungsvereinigung Antriebstechnik e.V., Lyoner Strasse 18, D-60528 Frankfurt/Main, 1993, pp. 1-8. 
Glovnea, R.P.; Spikes, H.A. "Elastohydrodynamic Film Formation at the Start-up of the Motion." Proc. IMechE, Part J, J. Engineering Tribol.; Vol. 215, 2001; pp. 125138.

Graham, R.C.; Olver, A.V.; Macpherson, P.B. "An Investigation into the Mechanisms of Pitting in High-Hardness Carburized Steels." American Society of Mechanical Engineers (ASME) Paper No. 80-C2/DET-118. New York: ASME, 1980; pp. 1-7.

Gunsel, S.; Korcek, S.; Smeeth, M.; Spikes, H.A. "The Elastohydrodynamic Friction and Film Forming Properties of Lubricant Base Oils." Tribol. T.; Vol. 42, No. 3, 1999; pp. 559-569.

Haizuka, S.; Naruse, C.; Tamenaga, J. "Study on Tooth Surface Strength of Spur Gears, Part I: Experimental Procedure and Determination of Tooth Surface Strength." Tribol. T.; Vol. 42, No. 1, 1999; pp. 76-83.

Haizuka, S.; Naruse, C.; Tamenaga, J. "Study on Tooth Surface Strength of Spur Gears, Part II: Special Attention on Effects of Lubricating Oil, Material and Tooth Surface Heat Treatment." Tribol. T.; Vol. 42, No.1, 1999; pp. 152-161.

Hashimoto, M.; Hoyashita, S.; Iwata, J. "Studies on Improvement of Surface Durability of Case-Carburized Steel Gear-Effects of Surface Finish Processes upon Oil Film Formation.” AGMA Paper No. 98FTM9. Alexandria, VA: AGMA, 1998; pp. 1-9.

Hoeprich, M.R. "Analysis of Micropitting on Prototype Surface Fatigue Test Gears." AGMA Paper No. 99FTM5. Alexandria, VA: AGMA, 1999; pp. 1-11.

Hohn, B.R.; Oster, P.; Emmert, S. "Micropitting in Case-Carburized Gears-FZG Micropitting Test." Journal VDI Berichte, NR. 1230, 1996, pp. 331-344.

Hohn, B.R.; Oster, P.; Michaelis, K. "New Test Methods for the Evaluation of Wear, Scuffing and Pitting Capacity of Gear Lubricants." AGMA Paper No. 98FTM8. Alexandria, VA: AGMA, 1998, pp. 1-10.

Hohn, B.R.; Michaelis, K.; Kopatsch, F. "Systematic Investigations on the Influence of Viscosity Index Improvers on EHL Film Thickness." Gear Technol.; Vol. 18, No. 6, Nov./Dec. 2001; pp. 30-39.

Hohn, B.R.; Oster, P.; Schrade, U.; Tobie, T. "Investigations on the Micropitting Load Capacity of Case Carburized Gears." AGMA Paper No. 04FTM5. Alexandria, VA: AGMA, 2004; pp. 1-13.

Holmes, M.J.A.; Evans, H.P.; Snidle, R.W. "Comparison of Transient EHL Calculations with Start-up Experiments." Proc. 29th Leeds-Lyon Symposium on Tribology, Leeds, September 2002, ISBN 0-444-51243-8. Elsevier, 2003; pp. 79-89.

Holmes, M.J.; Evans, H.P.; Snidle, R.W. "Comparison of Transient EHL Calculations with Shut-down Experiments." Proc. 29th Leeds-Lyon Symposium on Tribology, Leeds, September 2002, ISBN 0-444-51243-8. Elsevier, 2003; pp. 91-99.

Holmes, M.J.A.; Qiao, H.; Evans, H.P.; Snidle, R.W. "Surface Contact and Damage in Micro-EHL," in Life Cycle Tribology, Proc. 31st Leeds-Lyon Symposium on Tribology, Leeds, 2004, ISBN-0-444-51687 5. Tribology and Interface Engineering Series, Elsevier, 2005, pp. 605-616. 
Holmes, M.J.; Evans, H.P.; Snidle, R.W. "Analysis of Mixed Lubrication Effects in Simulated Gear Tooth Contacts.” J. Tribol.-T. ASME; ISSN 0742-4787, Vol. 127, 2005; pp. 61-69.

Hoyashita, S.; Hashimoto, M.; Seto, K. "Basic Studies on Fatigue Strength of CaseHardened Gear Steel_Effects of Shot Peening and/or Barrelling Processes." AGMA Paper No. 98FTM3. Alexandria, VA: AGMA, 1998; pp. 1-9.

Ichimaru, K.; Nakajima, A.; Hirano, F. "Effect of Asperity Interaction on Pitting in Rollers and Gears.” ASME Paper No. 80-C2/DET-36. New York: ASME, 1980; pp. $1-10$.

Ishibashi, A.; Ezoe, S.; Tanaka, S. "Mirror Finishing of Tooth Surfaces Using a Trial Gear Grinder with Cubic-Boron-Nitride Wheel.” ASME Paper No. 84-DET-153. New York: ASME, 1984; pp. 1-8.

Jacobson, B. Rheology and Elastohydrodynamic Lubrication. Amsterdam: Elsevier, 1991.

Jao, T.C.; Devlin, M.T.; Milner, J.L.; Iyer, R.N.; Hoeprich, M.R. "Influence of Surface Roughness on Gear Pitting Behavior.” AGMA Paper No. 04FTM4.

Alexandria, VA: AGMA, 2004; pp. 1-10.

Jao, T.C.; Rollin, A.J.; Carter, R.O.; Aylott, C.J.; Shaw, B.A. "Influence of Material Property on Micropitting and Pitting Behaviour." Proc. World Tribology Congress III, September 12-16, Washington, DC, USA, 2005.

Jao, T.C.; Guevremont, J.M.; Rollin, A.J.; Carter, R.O.; Aylott, C.J.; Shaw, B.A.; "Formation of Modified Martensite Regions in Gears." Proc. 16th International Colloquium on Tribology, January 17-19, Ostifildem, Germany, 2008.

Kim, T.H.; Olver A.V. "Stress History in Rolling-Sliding Contact of Rough Surfaces." Tribol. Int.; Vol. 31, No. 12, 1999; pp. 727-736.

Kim T.H.; Olver A.V. "Fatigue and Brittle Fracture Analysis of Surface Engineered Materials in Rolling Contact." Proc. 23rd Leeds-Lyon Symp. on Tribology:

Elastohydrodynamics. Dowson, D., ed., Elsevier, 1996; pp. 37-48.

Krantz, T.L.; Alanou, M.P.; Evans, H.P.; Snidle, R.W. "Surface Fatigue Lives of Case-Carburized Gears with an Improved Surface Finish." J. Tribol.-T. ASME; ISSN 0742-4787, Vol. 123, 2001; pp. 709-716.

Lainé, E.; Olver, A.V.; Beveridge, T.A. "Effect of Lubricants on Micropitting and Wear.” Tribol. Int.; ISSN: 0301-679X, Vol. 41, 2008, pp. 1049-1055.

Li, S.; Devlin, M.T.; Milner, J.; Iyer, R.; Jao, T.C.; Hoeprich, M.R.; Cameron, T.M. "Investigation of Pitting Mechanism in the FZG Pitting Test." SAE Paper No. 200301-3233. Warrendale, PA: SAE, 2003; pp. 1-15.

Littmann, W.E. "The Mechanism of Contact Fatigue." Interdisciplinary Approach to the Lubrication of Concentrated Contacts. NASA SP-237, 1970; pp. 309-377.

Littmann, W.E.; Widner, R.L.; Wolfe, J.O.; Stover, J.D. "The Role of Lubrication in Propagation of Contact Fatigue Cracks." J. Lubric. Tech.-T. ASME; Vol. 90, No. 1, 1968; pp. 89-100. 
MacPherson, P.B. "The Pitting Performance of Hardened Steels." ASME Paper No. 77-DET-39. New York: ASME, 1977; pp. 1-9.

Milburn, A.; Errichello R.; Godfrey, D. "Polishing Wear.” AGMA Paper No. 90FTM5. Alexandria, VA: AGMA, 1990; pp. 1-13.

Moyer, C.A. "Applying the Modified Lambda Ratio to Bearings and Gears." SAE 900910, 41st Annual Earthmoving Industry Conference, Peoria, IL, April 3-5, 1990.

Moyer, C.A.; Bahney, L.L. "Modifying the Lambda Ratio to Functional Line Contacts." Society of Tribologists and Lubrication Engineers (STLE) Preprint No. 89-TC-5A-1. Park Ridge, IL: STLE, 1989; pp. 1-7.

Nakajima, A. "Effect of Asperity Interacting Frequency on Surface Durability." Int. Symp. on Gearing and Power Transmissions, Tokyo, Paper b-26, 1981; pp. 401-406.

Nakanishi, T.; Ariura, Y. "Effect of Surface-Finishing on Surface Durability of Surface-Hardened Gears." MPT'91, Proc. JSME International Conference on Motion and Power Transmissions, Nov. 23-26, Hiroshima, 1991; pp. 828-833.

Nakatsuji, T.; Mori, A. "Pitting Durability of Electrolytically Polished Medium Carbon Steel Gears-Succeeding Report." Tribol. T.; Vol. 42, No. 2, 1999; pp. 393400.

Nakatsuji, T.; Mori, A. "Tribological Properties of Electrolytically Polished Surfaces of Carbon Steel.” Tribol. T.; Vol. 41, No. 2, 1998; pp. 179-188.

Nixon, H.P.; Zantopulos, H. "Lubricant Additives, Friend or Foe," Lubric. Eng.; Vol. 51, No. 10, 1995; pp. 815-822.

Oila, A.; Shaw, B.A.; Aylott, C.J.; Bull, S.J. "Martensite Decay in Micropitted Gears." Proc. Institution of Mechanical Engineers Part J-Journal of Engineering Tribology; Vol. 219, No. J2, 2005; pp. 77-83.

Olver, A.V. "Micropitting and Asperity Deformation." Developments in Numerical and Experimental Methods Applied to Tribology, Proc. 10th Leeds-Lyon Symp. on Tribology, 1983. Dowson, D.; Godet, M., eds. London: Butterworths, 1984; pp. 319323.

Olver, A.V.; Spikes, H.A.; Bower, A.F.; Johnson, K.L. "The Residual Stress

Distribution in a Plastically Deformed Model Asperity." Wear; Vol. 107, 1986, pp. 151-174.

Olver, A.V. "Temperature and Lubrication of Gears in High Speed Transmissions." IMechE Seminar on Lubricants and Lubrication Systems, Nov. 10, 1993, Solihull, UK. London: IMechE, 1993; pp. 1-11.

Olver, A.V. "Micropitting of Gear Teeth: Design Solutions.” Aerotech '95, NEC Birmingham October, London: IMechE, 1995, pp. 1-12.

Olver, A.V. "Gear Lubrication-A Review." Proc. IMechE, Part J, J. Engineering Tribology; ISSN 1350-6501, Vol. 216, 2002; pp. 255-267.

Olver, A.V. "The Mechanism of Rolling Contact Fatigue: An Update." Proc. IMechE, Part J, J. Engineering Tribology, Vol. 219, 2005; pp. 313-330. 
Olver, A.V.; Nicolson, D.M. "Tooth Tip Lubrication in Spur Gears." Proc. BGA Annual Congress, Sheffield, October 1995, Burton on Trent, Staffordshire, UK: British Gear Association, 1995; pp. 1-14.

Olver, A.V.; Tiew, L.K.; Medina, S.; et al. "Direct Observations of a Micropit in an Elastohydrodynamic Contact." Wear; ISSN 0043-1648, 2004, Vol. 256, pp. 168-175.

Olver, A.V.; Dini, D.; Lainé, E.; Hua, D.Y.; Beveridge, T.A. "Roughness and Lubricant Chemistry Effects in Micropitting." AGMA Paper No. 07FTM14, ISBN 978-1-55589-918-9. Alexandria, VA: AGMA, 2007; pp. 1-8.

Olver, A.V.; Dini, D. "Roughness in Lubricated Rolling Contact: The Dry Contact Limit." Proc. IMechE, Part J, J. Engineering Tribology, ISSN 1350-6501. Vol. 221, 2007; pp. 787-791

Olver, A.V.; Lainé; E., Dini, D.; Beveridge, T.A.; Hua, D.Y.; Shollock, B.A.; Lekstrom, M.F. "Effect of a Friction Modifier on Micropitting." Tribol. T. (in press), Jan 2009.

Onsy, A.; Bicker, R.; Shaw, B.A.; Steven, A.; Rowland, C.W.; Kent, T. "Monitoring the Progression of Micropitting in Helical Gears-Towards an Intelligent Health Monitoring System.” Proc. 51st Acoustic Emission Working Group Annual Meeting and International Symposium on Acoustic Emission, Memphis, USA. 13-15 October, 2008.

Parrish, G. Carburizing: Microstructures and Properties. 2nd ed. Materials Park, OH: ASM International, 1999; 247 pp.

Shaw, B.A.; Evans, J.T. "Micro-pits Under the Microscope." Paper 6, session 3. Proc. of British Gear Association Annual Congress, Drives and Controls Conference. Croydon, Surrey, UK: Kamtech Publishing, Telford, March 1997.

Shipley, E.E. "Failure Analysis of Coarse-Pitch, Hardened and Ground Gears." AGMA Paper No. P229.26. Alexandria, VA: AGMA, 1982; pp. 1-24.

Shotter, B.A. "Micropitting: Its Characteristics and Implications on the Test Requirements of Gear Oils." Performance and Testing of Gear Oils and Transmission Fluids, Institute of Petroleum, 1981, pp. 53-60 and 320-323.

Smith, R.E.; Errichello, R.; McVittie, D. "Designing Hardened \& Ground Spur Gears to Operate with Minimum Noise." Gear Technol.; Vol. 11, No. 3, May/June 1994; pp. 43-45.

Snidle, R.W.; Evans, H.P.; Alanou, M.P.; Holmes, M.J.A. "Understanding Scuffing and Micropitting of Gears." Presented at NATO Research and Technology Organisation Specialists' Meeting on the Control and Reduction of Wear in Military Platforms. AVT-109 RTO-MP-AVT-109, Vol. 14. NATO Research and Technology Organisation, Applied Vehicle Technology Panel, 2004; pp. 1-18.

Spikes, H.A.; Olver, A.V.; Macpherson, P.B. "Wear in Rolling Contacts." Wear; Vol. 112, No. 2, 1986; pp. 121-144.

Sroka, G.; Winkelmann, L. "Superfinishing Gears - The State of the Art." Gear Technol.; Vol. 20, No. 6, Nov./Dec. 2003; pp. 28-33. 
Strachan, D.C.; Paul, D.M.; Bowen, A.W. "Investigation of a Laser Scattering Technique for the Study of Micropitting in Test Gears." Wear; Vol. 72, 1981, pp. 219-236.

Tanaka, S.; Ishibashi, A.; Ezoe, S. “Appreciable Increases in Surface Durability of Gear Pairs with Mirror-Like Finish.” ASME Paper No. 84-DET-223. New York: ASME, 1984; pp. 1-8.

Tao, J.; Hughes, T.G.; Evans, H.P.; Snidle, R.W. "Elastohydrodynamic Response of Transverse Ground Gear Teeth." Proc. 28th Leeds-Lyon Symp. on Tribology, ISBN 0444-50969-0, 2002, pp. 447-458.

Tao, J.; Hughes, T.G.; Evans, H.P.; Snidle, R.W.; Hopkinson, N.A.; Talks, M.; Starbuck, J.M. "Elastohydrodynamic Lubrication Analysis of Gear Tooth Surfaces from Micropitting Tests." J. Tribol.-T. ASME; ISSN 0742-4787, Vol. 125, 2003, pp. 267-274.

Thomas, T.R.; Sayles, R.S. "The Application of Measurements of Surface Roughness to Tribological Problems." Proc. IMechE; 1978, pp. 47-52.

Tokuda, M.; Ito, S.; Muro, H.; Oshima, T. "Evaluation of Lubricants by an Accelerated Peeling Test." Published in Tourret, R.; Wright, E.P., eds., Rolling Contact Fatigue, Performance Testing of Lubricants. London: Heyden and Son, 1977; pp. 107-115.

Torrance, A.A.; Morgan, J.E.; Wan, G.T.Y. “An Additive's Influence on the Pitting and Wear of Ball Bearing Steel." Wear; Vol. 192, 1996; pp. 66-73.

Townsend, D.P.; Shimski, J. "Evaluation of the EHL Film Thickness and Extreme Pressure Additives on Gear Surface Fatigue Life." NASA Technical Memorandum 106663, 1994, pp. 1-8.

Ueno, T.; Ariura, Y.; Nakanishi, T. "Surface Durability of Case-Carburized GearsOn a Phenomenon of 'Gray-Staining' of Tooth Surface." ASME Paper No. 80C2/DET-27. New York: ASME, 1980; pp. 1-8.

Webster, M.N.; Sayles, R.S. "A Numerical Model for the Elastic Frictionless Contact of Real Rough Surfaces.” J. Tribol.-T. ASM; Vol. 108, 1986; pp. 314-320.

Webster, M.N.; Norbart, C.J.J. “An Experimental Investigation of Micropitting Using a Roller Disk Machine.” Tribol. T.; Vol. 38, No. 4, 1995; pp. 883-893.

Welsch, W. "Lubricating Properties of Shot-Peened Gears." Lubric. Eng.; Vol. 54, No. 2, 1998; pp. 26-28.

Wilkinson, C.M.R.; Olver, A.V. "The Durability of Gear and Disc Specimens. Part 1: The Effect of Some Novel Materials and Surface Treatments." Tribol. T.; Vol. 42, No. 3, 1999; pp. 503-510.

Wilkinson, C.M.R.; Olver, A.V. "The Durability of Gear and Disc Specimens. Part 2: Post Failure Examination and Gear-Disc Correlation.” Tribol. T.; Vol. 42, No. 3 , 1999; pp. 610-618.

Winter, H.; Oster, P. "Influence of Lubrication on Pitting and Micropitting Resistance of Gears.” Gear Technol.; Vol. 7, No. 2, March/April, 1990; pp. 16-23. 
Winter, H.; Oster, P. "Influence of the Lubricant on Pitting and Micropitting (Grey Staining, Frosted Areas) Resistance of Case Carburized Gears-Test Procedures.” AGMA Paper No. 87FTM9. Alexandria, VA: AGMA, 1987; pp. 1-8.

Winter, H.; Weiss, T. "Some Factors Influencing the Pitting, Micropitting (Frosted Areas) and Slow Speed Wear of Surface Hardened Gears." ASME Paper No. 80C2/DET-89. New York: ASME, 1980; pp. 1-7.

Yoshizaki, M.; Hashimoto, T.; Kasamatsu, C. "Effect of Abnormal Surface Layer on Tooth Surface Strength Increase of Gas Carburized Gears.” Tribol. T.; Vol. 46, No. 1, 2003; pp. 83-94.

Zhou, R.S. "Surface Topography and Fatigue Life of Rolling Contact Bearings."

STLE Preprint No. 92-TC-5E-1. Park Ridge, IL: STLE, 1992; pp. 1-12.

Zhu, D.; Hu, Y. "Effect of Rough Surface Topography and Orientation on the Characteristics of EHD and Mixed Lubrication in both Circular and Elliptical Contacts.” Tribol. T.; Vol. 44, No. 3, 2001; pp. 391-398.

Zhu, D. "Effect of Surface Roughness on Mixed EHD Lubrication Characteristics." Tribol. T.; Vol. 46, No. 1, 2003; pp. 44-48. 


\section{Appendix A: Information on Attendees}

\section{A.1 Speaker Biographies}

The following biographies give information on the speakers. See Section A.2 for contact information.

\section{Robert Errichello}

President, GEARTECH, Townsend, MT, USA

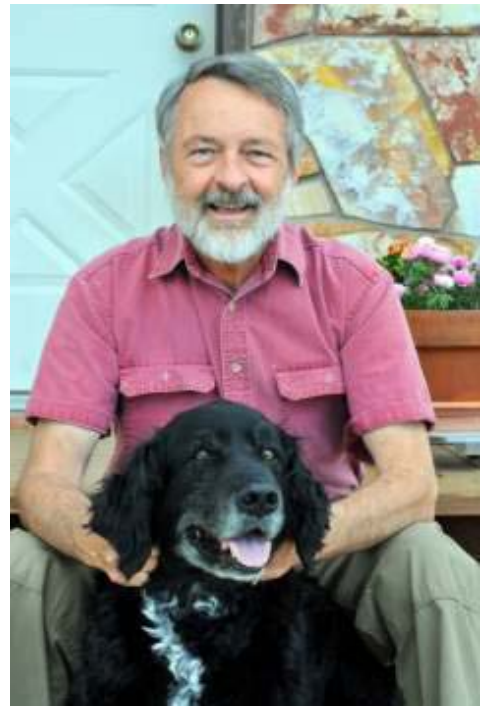

Robert Errichello heads his own gear consulting firm, GEARTECH, and is the founder of GEARTECH Software, Inc. He has more than 40 years of industrial experience and has worked for several gear companies. For the past 31 years, he has worked as a consultant to the gear industry, as well as to more than 40 wind turbine manufacturers, purchasers, operators, and researchers.

Errichello is a graduate of the University of California at Berkeley and holds his B.S. and M.S. in mechanical engineering, along with a master's of engineering in structural dynamics. Errichello has taught courses in material science, fracture mechanics, vibration, and machine design at San Francisco State University and the University of California at Berkeley. He has also presented numerous seminars on design, analysis, lubrication, and failure analysis of gears and bearings to professional societies; technical schools; and the gear, bearing, and lubrication industries.

Errichello is a registered professional engineer in the state of California, and a member of several committees, including the American Gear Manufacturers Association (AGMA) Gear Rating Committee, the AGMA/American Wind Energy Association (AWEA) Wind Turbine Committee, and the American Society of Mechanical Engineers (ASME) Power Transmission and Gearing Committee. He is a member of AGMA, ASM International, ASME, the Society of Tribologist and Lubrication Engineers (STLE), NREL's Gearbox Reliability Collaborative (GRC), and the Montana Society of Engineers.

Errichello has published more than 60 articles on design, analysis, and application of gears, and is the author of three widely used computer programs for design and analysis of gears. He is a technical editor for Gear Technology and STLE's Tribology Transactions.

Errichello is recipient of the AGMA Technical Division Executive Committee (TDEC) Award, the AGMA E.P. Connell Award, the AGMA Lifetime Achievement Award, the STLE Wilbur Deutch Memorial Award, and the AWEA Technical Achievement Award. 


\section{Stephen Hsu, Ph.D.}

Professor, Department of Mechanical \& Aerospace Engineering, George Washington University, Washington, D.C., USA

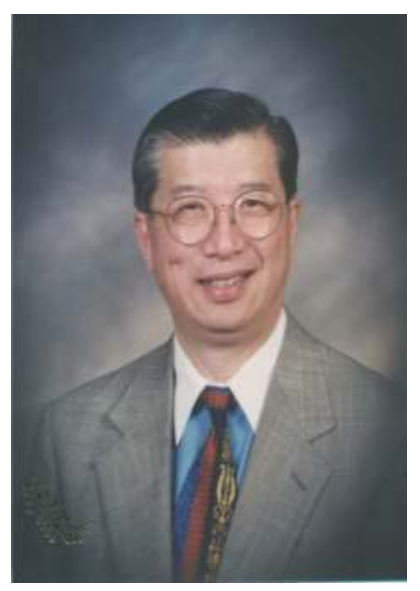

Stephen Hsu obtained his B.S. at Virginia Tech and M.S. and $\mathrm{Ph} . \mathrm{D}$. degrees in chemical engineering from The Pennsylvania State University. After graduation, he joined the Amoco Chemicals Research Lab in Naperville, Illinois. In 1978, he joined the National Institute of Standards and Technology (NIST) to lead a U.S. congressionally mandated program on recycled oils. After successfully concluding the program in 1984, he established his own research group on tribochemistry. After a stint as the founding division chief of the Ceramic Division, he went back to basic research and began working closely with various industries on a variety of technical issues challenging the economy: machining of advanced materials, magnetic hard disk interface, lubrication of new materials, wear maps to guide materials selection, nanofriction, and nanomechanical properties of nanomaterials. He has published some 250 papers, received 7 U.S. patents, and given about 40 plenary lectures in international conferences. He was a visiting professor at Pennsylvania State, Esback Fellow at Northwestern University, and adjunct professor at University of Maryland, where he supervised M.S. and Ph.D. theses.

He is a Fellow of ASME, STLE, and the recipient of STLE International Award, Captain Alfred Hunt Memorial Medal, Al Sontag Award, and Bronze and Silver Medals from NIST. He served on the editorial boards of Tribology Letters and Tribology International, and has been a foreign expert reviewer for European Science Foundation, Australia, Canada, Singapore, Hong Kong, and Sweden, among others.

In January 2007, he joined George Washington University (GWU) as a professor of engineering and applied science, and in 2009, he cofounded the GWU Energy Institute. His current research focuses on wind energy, gear reliability, advanced materials for blades, self-repairing technology, and advanced coating development.

\section{Michael N. Kotzalas, Ph.D., P.E.}

Chief Engineer, Product Design, Global TRB, The Timken Company, Canton, OH, USA

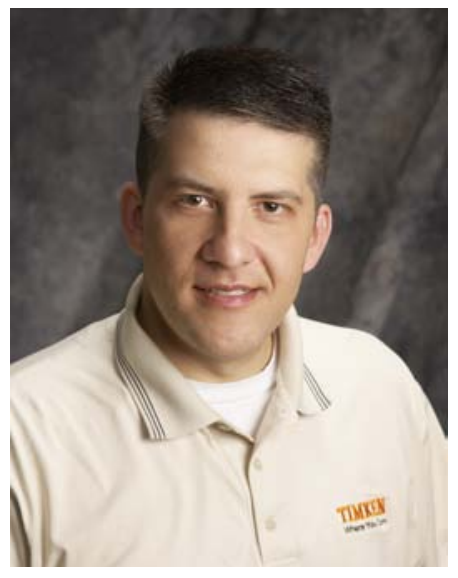

Michael Kotzalas attended The Pennsylvania State University, graduating with a B.S. in 1994, an M.S. in 1997, and a Ph.D. in 1999. All his degrees are in mechanical engineering. The focus of his university study and research was the analysis of rolling bearing technology, including quasi-dynamic modeling of ball and cylindrical roller bearings for high acceleration applications and spall progression testing and modeling for use in condition-based maintenance algorithms.

Since graduation, Kotzalas has been employed by The Timken Company within technology unit and most recently 
the bearings and power transmission business unit. His current responsibility is to globally coordinate and lead the design of tapered roller bearings for the Timken Company. Other responsibilities included leading the needle roller bearing design group for off-highway customers, new product development, and analysis algorithm research and development. From this work, Kotzalas has received two U.S. patents for cylindrical roller bearing designs.

Outside of work, Kotzalas is also active in industrial societies. A member of ASME, he serves as the secretary and treasurer of the Tribology Division, and previously served as chair of the Publications Committee and webmaster of the Tribology Division. With STLE, he previously served as chair of the Awards Committee. Also, Kotzalas has published 13 peer-reviewed papers in journals and conference proceedings, and coauthored the fifth edition of the two-volume book titled Rolling Bearing Analysis. Working with the American Bearing Manufacturer's Association (ABMA), Kotzalas is one of many instructors for short courses on "Advanced Concepts of Bearing Technology" and "Essential Concepts of Bearing Technology."

Kotzalas received the ASME Tribology Division's Best Paper Award in 2001 and STLE's Hodson Award in 2003 and 2006. In 2007, He was awarded the Outstanding Young Engineer for the Off-Highway Industry by the Society of Automotive Engineers (SAE) and the Association of Equipment Manufacturers (AEM).

\section{Andy Olver, Ph.D.}

Reader, Department of Mechanical Engineering, Imperial College, London, UK

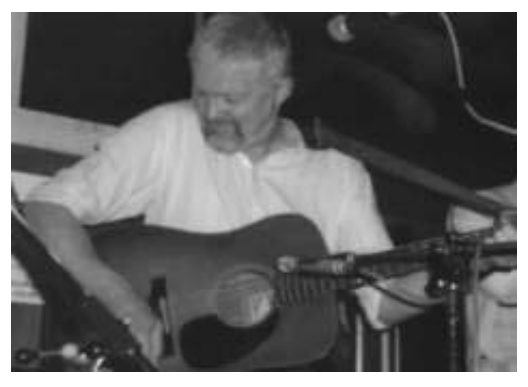

Andy Olver is a reader, the rank between senior lecturer and professor, in the Department of Mechanical Engineering at Imperial College, UK. He worked as a materials scientist, tribologist, and transmission engineer in the helicopter industry before joining the staff of Imperial College in 1992. His research interests include lubrication, fretting, rolling contact fatigue, and tribological materials.

Olver is part of the tribology group at the Imperial College. His motivation springs from the desire to solve practical engineering problems by making advances in fundamental understanding of tribology. Andy has contributed to the tribology group's research in experiments on rolling contact fatigue and fretting, theoretical modeling of spline couplings, microstructural studies of contact damage and gear, and rolling bearing tribology. His current projects include running-in and damage accumulation in rolling contact, and texture and roughness effects in hydrodynamic and elastohydrodynamic lubrication and diesel engine friction.

Olver's work has been published in peer-reviewed journals, conference proceedings, and book chapters. He was awarded the William Sweet Smith Prize under the Aerospace Industries Division of IMechE in 1992. He also won the PE publishing award for the Journal of Engineering Tribology under IMechE in 2005. 
Olver is a member of the Tribology Group Committee and Technical Activity Committee on Aircraft Transmissions, an academic member of the National Advisory Committee on Transmissions and Mechanical Systems, and a member of the editorial board for Proceedings of International Mechanical Engineers Part J. He was also a member of the tribology steering group for Engineering Sciences Data Unit.

More details on Olver can be found at: http://www3.imperial.ac.uk/people/a.v.olver

\section{Brian Shaw, Ph.D.}

Director, Design Unit, Newcastle University, UK

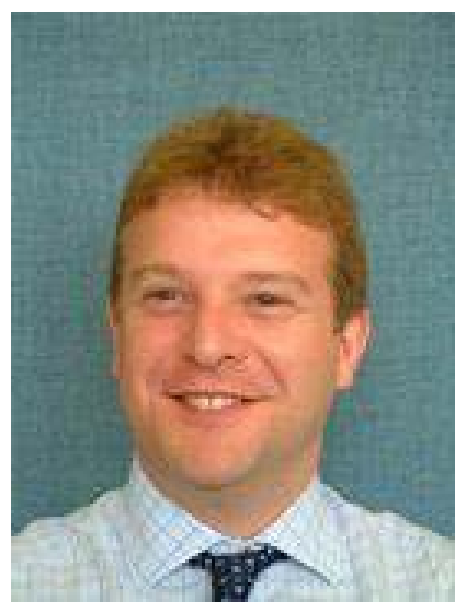

Brian Shaw is director of the Design Unit at Newcastle University (www.ncl.ac.uk/gears); he has more than 15 years of experience researching gear metallurgy and failure processes and carrying out industry-related failure investigations, including work on bearings. This has led to more than 90 scientific publications and more than 200 technical reports to industry. Shaw is the primary metallurgical gearing consultant to the UK Navy and also leads gear failure training for the British Gear Association, of which he is a member of Executive Board and Technical and Research Committee. Shaw is also a member of the UK BSI committee contributing to the review of ISO6336-5 on gear material specification and the development of micropitting gearing standards through ISO WG15. Shaw's research interests include improving gearing performance through material and processing developments assessed by testing gears on sophisticated gear test rigs developed at Newcastle University. Particular current interests include understanding methods to prevent micropitting, strength enhancements through control of residual stresses with novel methods (e.g., laser peening), improving performance through design optimization of microgeometry, and the use of coatings to enhance contact fatigue performance. Shaw leads a group of 22 staff in the Design Unit working across the board on gearing and transmissions research and development covering gear design, transmission testing, general mechanical design, bespoke test rigs, in-service measurement and condition monitoring, materials analysis, failure investigations, metrology, and seminars and training. 


\section{Ray Snidle, Ph.D.}

Professor, Department of Mechanical Engineering, Cardiff University, UK

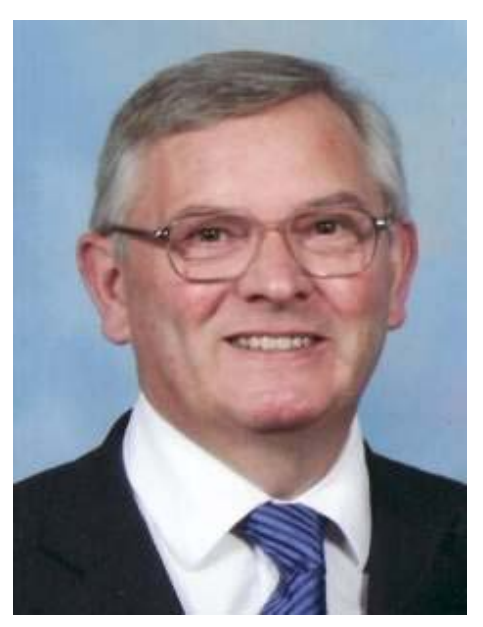

Ray Snidle is a professor of mechanical engineering in the School of Engineering at Cardiff University, where he leads the Tribology and Contact Mechanics Group. His research is mainly concerned with fundamental aspects of surface durability in machine elements such as gears, bearings, and other concentrated rolling/sliding contacts where the mechanism of lubrication is described as elastohydrodynamic or micro-elastohydrodynamic. He is currently leading a major EPSRC-sponsored project on "Mixed lubrication, wear and contact fatigue of rough surfaces." He recently completed an experimental investigation of the effects of hard coatings on the scuffing resistance of gears. Ray holds his Ph.D. and D.Sc. from Leicester University in the United Kingdom and is a fellow of ASME. His Web site can be found at http://tribology.engineering.cf.ac.uk/.

\section{Thomas Tobie, Ph.D.}

Gear Research Centre, Technical University of Munich, Germany

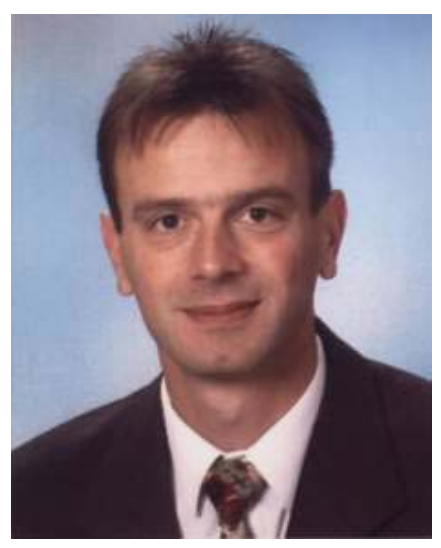

Thomas Tobie works at the Gear Research Centre (FZG) at Munich as associate to Prof. Dr.-Ing. B.-R. Höhn. He has been a chief engineer at FZG since 1999. In 2001 he graduated with the title of Dr.-Ing. He specializes in gear material, heat treatment, and gear load capacity research on tooth root bending fatigue, pitting, and micropitting. 


\section{Martin N. Webster, Ph.D.}

ExxonMobil Corporate Strategic Research, Annadale, NJ, USA

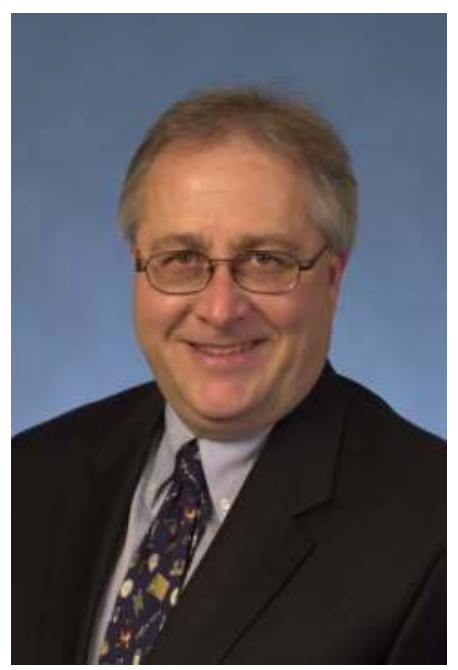

Martin Webster currently holds the position of senior research associate and program leader at ExxonMobil's Corporate Strategic Research laboratory in Annandale, New Jersey. He is responsible for a number of the longer range lubrication and tribology research programs.

Webster gained his Ph.D. in tribology from Imperial College London, where his work on rough surface contact mechanics resulted in being awarded the I Mech. E Tribology Bronze Medal in 1986. Following a postdoctoral assignment with Shell Research in the UK, he spent 2 years working on the design and analysis of wind turbine systems with the UKbased Wind Energy Group (WEG). He has since accumulated more than 20 years of experience working with ExxonMobil in both research and product development positions. His research focus has been on the fundamentals of lubricated contacts, including the measurement and characterization of EHL performance, modeling EHL contacts, rolling contact fatigue phenomenon and the interactions of lubricant components with engineering surfaces. He has published numerous papers and patents in each of these areas. He has been active in various societies and technical committees, including the Gear Research Institute, the ASME Rolling Element Bearing Committee, and the STLE Gears and Gear Lubrication technical committee. He currently serves as a director of the STLE.

\section{Lavern (Vern) D. Wedeven, Ph.D.}

President, Wedeven Associates, Inc., Edgemont, PA, USA

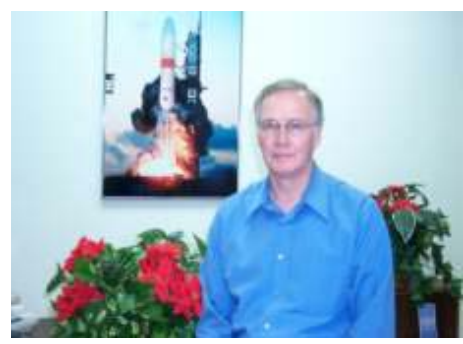

Vern Wedeven is president of Wedeven Associates, Inc., a small business devoted to tribology research and development. Since 1987 he and his associates have developed specialized tribology test machines and test methods that link fundamental principles of tribology to service applications. Wedeven Associates Machine (WAM) technology is providing tribology research capability for major bearing companies, military laboratories, and research institutes. He is involved in major research projects and consulting that serve aerospace and other industries.

Wedeven is a graduate of Calvin College (B.S.), University of Michigan (B.S.ME) and Imperial College, London (Ph.D.). Previous employment includes NASA Glenn Research Center, NASA Headquarters, and SKF-America. He is the author of more than60 technical papers in the area of tribology. He has written chapters in three books and holds three patents. He is the recipient of several awards: Walter D. Hodson Award (1975) for best published paper in STLE by an author under the age of 35 years; Captain Alfred E. Hunt Award (1979) for best paper published in STLE; Arch T. Colwell Cooperative Engineering Medal for contributions of SAE Propulsion Lubricants Committee; and the STLE International Award (2008) for outstanding contributions in tribology. 


\section{A.2 Attendee List}

\begin{tabular}{|c|c|c|c|}
\hline \# & Name & Affiliation & Email Address \\
\hline 1 & Peter J. Blau & ORNL & blaupi@ornl.gov \\
\hline 2 & Sandy Butterfield & NREL & Sandy.Butterfield@nrel.gov \\
\hline 3 & Jim Carey & ExxonMobil & ¡im.t.carey@exxonmobil.com \\
\hline 4 & Ekkehard Daschner & ExxonMobil & ekkehard.daschner@exxonmobil.com \\
\hline 5 & Kevin Dinwiddie & Amsoil & kdinwiddie@amsoil.com \\
\hline 6 & Gary Doll & Timken & gary.doll@timken.com \\
\hline 7 & Ali Erdemir & Argonne National Lab. & erdemir@anl.gov \\
\hline 8 & Bob Errichello & GEARTECH & geartech@mt.net \\
\hline 9 & Ed Hahlbeck & PowerTrain ENG & ehahlbeck@wi.rr.com \\
\hline 10 & Ted Harris & Harris Consulting & tah10@psu.edu \\
\hline 11 & Bill Herguth & Herguth Lab & wherguth@herguth.com \\
\hline 12 & Donald R. Houser & OSU Gear Lab & houser.4@osu.edu \\
\hline 13 & Stephen Hsu & $\begin{array}{c}\text { George Washington } \\
\text { University }\end{array}$ & stephen.hsu@erols.com \\
\hline 14 & Peter Jacobs & ExxonMobil & peter.w.jacobs@exxonmobil.com \\
\hline 15 & James A Johnson & NREL & James.A.Johnson@nrel.gov \\
\hline 16 & Michael N. Kotzalas & Timken & michael.kotzalas@timken.com \\
\hline 17 & Jon Leather & Castrol & jon.leather@castrol.com. \\
\hline 18 & Hal Link & NREL & Hal.Link@nrel.gov \\
\hline 19 & Matthew Malkin & DNV GEC & Matthew.Malkin@dnv.com \\
\hline 20 & David Mikalonis & SKF & david.r.mikalonis@skf.com \\
\hline 21 & Andy Milburn & Milburn Engineering & andy@milburnengineering.com \\
\hline 22 & Jane Muller & GEARTECH & jirmgears@mt.net \\
\hline 23 & Andy Olver & Imperial College & a.v.olver@ic.ac.uk \\
\hline 24 & Francisco Oyague & NREL & Francisco.Oyague@nrel.gov \\
\hline 25 & David Pallister & SKF & Dave.M.Pallister@skf.com \\
\hline 26 & Don Roberts & DNV GEC & Donald.Roberts@dnv.com \\
\hline 27 & Brian Shaw & University of Newcastle & b.a.shaw@newcastle.ac.uk \\
\hline 28 & Shawn Sheng & NREL & Shuangwen.Sheng@nrel.gov \\
\hline 29 & Ray Snidle & Cardiff University & snidler@cf.ac.uk \\
\hline 30 & Thomas Tobie & FZG-TU-Munich & tobie@fzg.mw.tum.de \\
\hline 31 & Martin Webster & ExxonMobil & martin.n.webster@exxonmobil.com \\
\hline 32 & Vern Wedeven & Wedeven Associates, Inc. & wedeven@aol.com \\
\hline
\end{tabular}




\section{A.3 Group Photo}

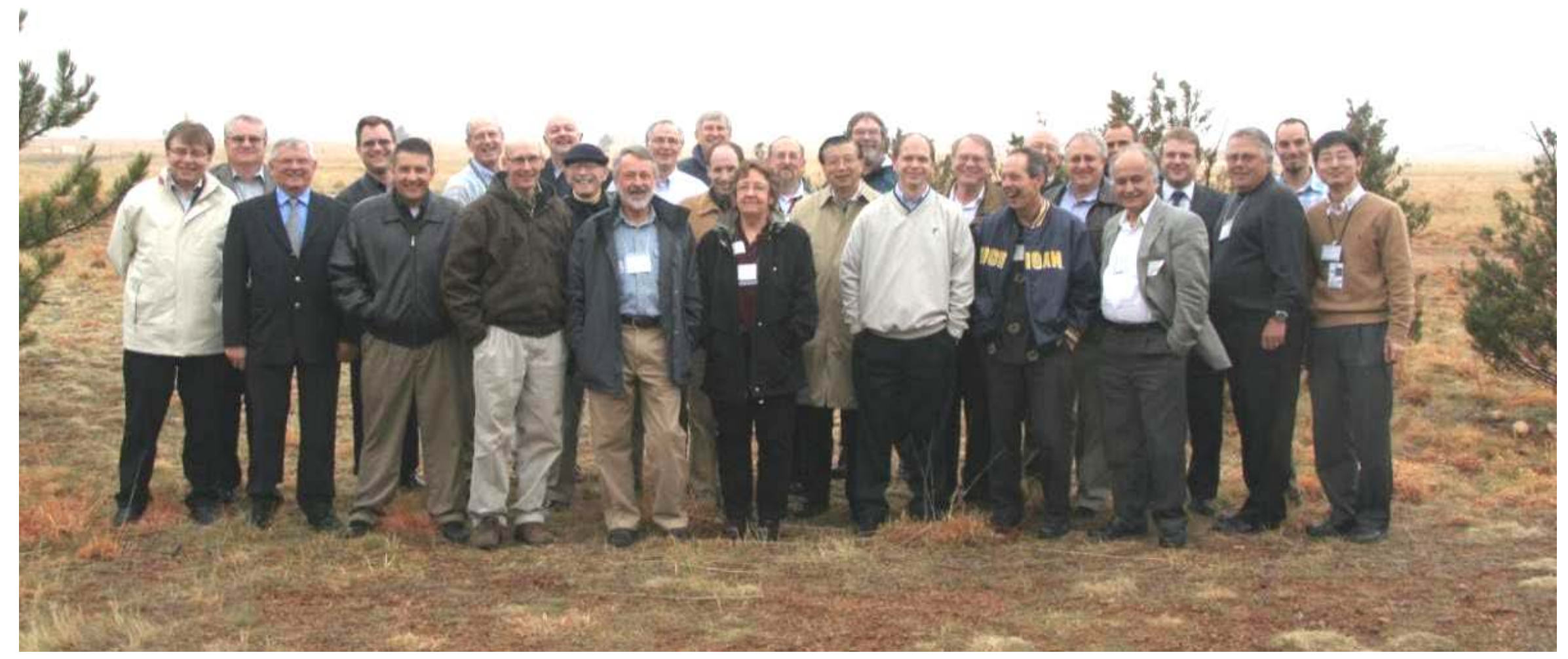

Left to Right: Ekkehard Daschner, Gary Doll, Ray Snidle, Peter Jacobs, Michael N. Kotzalas, Sandy Butterfield, Don Roberts, Andy Olver, Ted Harris, Bob Errichello, Vern Wedeven, Andy Milburn, Matthew Martin, Jane Muller, Peter Blau, Stephen Hsu, Jim Carey, David Mikalonis, Ed Hahlbeck, David Pallister, Don Houser, Martin Webster, Thomas Tobie, Ali Erdemir, Brian Shaw, Bill Herguth, Francisco Oyague, Shawn Sheng 


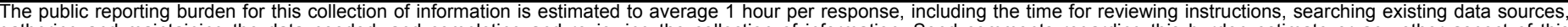

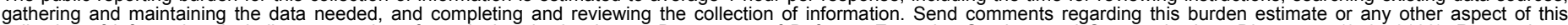

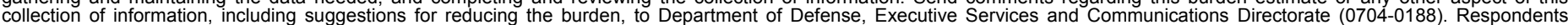

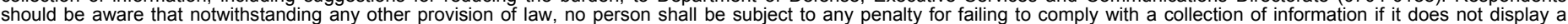

should be aware that notwithstanding

PLEASE DO NOT RETURN YOUR FORM TO THE ABOVE ORGANIZATION.

\begin{tabular}{l|ll} 
1. & REPORT DATE $(D D-M M-Y Y Y Y)$ \\
February 2010 & 2. & REPORT TYPE \\
& Technical Report
\end{tabular}

4. TITLE AND SUBTITLE

Wind Turbine Micropitting Workshop: A Recap
3. DATES COVERED (From - To)

April 15-16, 2009

5a. CONTRACT NUMBER

DE-AC36-08-GO28308

5b. GRANT NUMBER

5c. PROGRAM ELEMENT NUMBER

5d. PROJECT NUMBER

NREL/TP-500-46572

5e. TASK NUMBER

WE101131

5f. WORK UNIT NUMBER
7. PERFORMING ORGANIZATION NAME(S) AND ADDRESS(ES)

National Renewable Energy Laboratory

1617 Cole Blvd.

Golden, CO 80401-3393
8. PERFORMING ORGANIZATION REPORT NUMBER

NREL/TP-500-46572

9. SPONSORING/MONITORING AGENCY NAME(S) AND ADDRESS(ES)

10. SPONSOR/MONITOR'S ACRONYM(S)

NREL

11. SPONSORING/MONITORING AGENCY REPORT NUMBER

12. DISTRIBUTION AVAILABILITY STATEMENT

National Technical Information Service

U.S. Department of Commerce

5285 Port Royal Road

Springfield, VA 22161

13. SUPPLEMENTARY NOTES

14. ABSTRACT (Maximum 200 Words)

Micropitting is a Hertzian fatigue phenomenon that affects many wind turbine gearboxes, and it affects the reliability of the machines. With the major growth and increasing dependency on renewable energy, mechanical reliability is an extremely important issue. The U.S. Department of Energy has made a commitment to improving wind turbine reliability and the National Renewable Energy Laboratory (NREL) has started a gearbox reliability project. Micropitting as an issue that needed attention came to light through this effort. To understand the background of work that had already been accomplished, and to consolidate some level of collective understanding of the issue by acknowledged experts, NREL hosted a wind turbine micropitting workshop, which was held at the National Wind Technology Center in Boulder, Colorado, on April 15 and 16, 2009.

15. SUBJECT TERMS

micropitting; Hertzian fatigue phenomenon; wind turbine gearboxes; wind turbine reliability; turbine micropitting workshop

\begin{tabular}{|c|c|c|}
\hline $\begin{array}{l}\text { a. REPORT } \\
\text { Unclassified }\end{array}$ & $\begin{array}{l}\text { b. ABSTRACT } \\
\text { Unclassified }\end{array}$ & $\begin{array}{l}\text { c. THIS PAGE } \\
\text { Unclassified }\end{array}$ \\
\hline
\end{tabular}

\begin{tabular}{|c|c|} 
17. LIMITATION \\
OF ABSTRACT \\
UL
\end{tabular}

19a. NAME OF RESPONSIBLE PERSON

19b. TELEPHONE NUMBER (Include area code) 